bioRxiv preprint doi: https://doi.org/10.1101/2021.03.08.434344; this version posted March 8, 2021. The copyright holder for this preprin (which was not certified by peer review) is the author/funder, who has granted bioRxiv a license to display the preprint in perpetuity. It is made available under aCC-BY-NC-ND 4.0 International license.

\title{
Efficient graphene oxide coating improves cryo-EM sample preparation and data collection from tilted grids
}

Avinash Patel ${ }^{1,2^{*}}$, Daniel Toso ${ }^{3}$, Audrey Litvak ${ }^{4}$, Eva Nogales ${ }^{3,4,5,6}$

1 Biophysics Graduate Group, UC Berkeley

2 Present address: Molecular Bioscience Department, Northwestern University

3 QB3 Institute, UC Berkeley

4 Molecular and Cell Biology Department, UC Berkeley

5 MBIB Division, Lawrence Berkeley National Laboratory

6 HHMI, Berkeley

*Corresponding author: avinash.patel@northwestern.edu

\begin{abstract}
Recent technical developments have made single particle cryo-EM a major structural biology technique, especially in the characterization of challenging samples that resist crystallization, can only be obtained in small amounts, or suffer from compositional or conformational heterogeneity. However, a number of hurdles that often challenge sample preparation still need to be overcome in order to increase the applicability and throughput of cryo-EM. These technical hurdles include obtaining enough particles per image, with close to random orientation, and without damage from interaction with the air-water interface. While coating EM grids with graphene oxide is a promising procedure for the improvement of sample preparation, it suffers from some technical problems that limit its applicability. We have modified the established drop cast method for adhering graphene oxide onto holey patterned grids to increase graphene coverage. Our method relies on the use of a polycationic polymer to coat the surface of the grid prior to graphene oxide application, thereby preventing the repulsion of the negatively charged graphene oxide sheets from the negatively charged grid surface. With this improved preparation method, we show that graphene oxide supports can increase the number of particles in the field of view by an order of magnitude with respect to open holes, while keeping them away from the damaging air-water interface. We also show how graphene oxide coated gold foil grids can be used to collect tilted cryoEM data in order to overcome preferred orientation issues, without experiencing the large amount of drift observed with conventional amorphous carbon supports, thus allowing data collection that can lead to high-resolution reconstructions.
\end{abstract}


bioRxiv preprint doi: https://doi.org/10.1101/2021.03.08.434344; this version posted March 8, 2021. The copyright holder for this preprint (which was not certified by peer review) is the author/funder, who has granted bioRxiv a license to display the preprint in perpetuity. It is made available under aCC-BY-NC-ND 4.0 International license.

\section{Introduction}

Developments in direct electron detector technology and computational image processing tools in the past decade have made single particle cryo-electron microscopy (cryo-EM) a leading method for the determination of macromolecular structures alongside X-ray crystallography and nuclear magnetic resonance spectroscopy. As a single particle technique, cryo-EM has the advantage of being able to determine the structures of large, flexible, and heterogeneous molecules, as each particle can be classified and individual domains refined separately, all with the need for only small amounts of sample ${ }^{1}$.

Though cryo-EM enables us to look at many new samples, it does come with its own difficulties. A major barrier in obtaining a high-quality reconstruction is preparing a high-quality sample, in which the particles are densely packed, yet separated, randomly oriented, and undamaged ${ }^{2}$. In order to fulfill these needs, many methods have been devised and used to varying levels of success.

Increased sample concentration is the easiest way to image a greater number of particles without compromising data quality by lowering the imaging magnification or increasing the data collection time at a corresponding increased cost. If concentrated samples are not feasible during biochemical preparation, the main method of obtaining more particles is to use a support layer over the EM grid that binds the particles, effectively concentrating them by adsorption. The simplest and most popular support is a thin layer of amorphous carbon ${ }^{3}$, but graphene ${ }^{4-8}$, graphene oxide ${ }^{9-11}$, or lipid monolayers ${ }^{12,13}$ have also been used. Adsorption to a support layer generally results in increased particle numbers with increasing incubation times ${ }^{14,15}$. In addition to a simple support layer, affinity grids have been developed with specific interacting groups to capture molecules in solution ${ }^{13,16-19}$. In the absence of a continuous support layer, molecules may preferentially localize to the holey support layer of the grid. Another approach to increase particle numbers in open holes has therefore been to passivate the grid to make it easier for the applied sample to enter/remain in the hole ${ }^{20-22}$.

The damaging effect of the hydrophobic air-water interface results in the breakdown of many fragile complexes, causing subunits to dissociate and/or proteins to denature ${ }^{6,23}$. There are several approaches that aim to solve this problem, including the addition of small amounts of detergents to the sample ${ }^{24}$, stabilizing the protein complexes by optimizing the buffer conditions (buffers containing sugars and/or glycerol) ${ }^{25,26}$, crosslinking the sample ${ }^{14}$, sequestering the particles away from the air-water interface by binding them to a support layer ${ }^{16,27,28}$, or reducing the exposure time to the air-water interface by rapid freezing of the sample following blotting ${ }^{23,29}$.

Reconstruction of a three-dimensional object from two-dimensional projection images requires multiple views of the complex. While in solution, particles are tumbling and assume completely random orientations. However, during cryoEM sample preparation, particles tend to adhere to available surfaces (support layer or air-water interface), which tends to predominantly occur with specific surfaces of the particles, resulting in preferred orientations (e.g. hydrophobic patches will bind the air-water interface). Efforts to overcome this issue include the addition of detergents ${ }^{24,30-32}$, glow discharging the grid in the presence of different residual chemical groups ${ }^{33-35}$, coating the grids with different polymers ${ }^{36,37}$, deforming the grid ${ }^{38}$, or tilting the grid during data collection ${ }^{39}$. Except for tilting the grid, none of these methods is generally applicable, leading to lengthy screening procedures that may not always prove effective ${ }^{40}$. Unfortunately, while tilting has been shown to be most successful to produce multiple views when samples are prepared using open holes ${ }^{39}$, this type of sample may suffer from the previous two problems, and requires the use of gold foil grids in order to reduce the beaminduced motion ${ }^{41}$ observed for tilted specimens. While attempts have been made to use amorphous carbon coated grids to collect tilted data, the resulting structures ${ }^{42,43}$ have not been able to reach the resolution of structures collected in open holes.

Here we show how pretreatment of the grid with a polycationic polymer, such as polyethyleneimine (PEI), can significantly increase the coverage of graphene oxide onto holey patterned grids. We show that such grids can increase particle concentration by an order of magnitude compared to the same sample prepared on open hole grids due to the adsorption of particles onto the graphene oxide sheet, while at the same time being kept away from the damaging airwater interface. Lastly, we demonstrate that graphene oxide-coated gold foil grids can be used to collect tilted cryo-EM data without experiencing large amounts of drift that would otherwise dampen the high-resolution signal.

\section{Preparation of graphene oxide coated grids}

Graphene oxide is a near-ideal support layer for cryo-EM. It produces minimal background in cryo-EM images, is sufficiently hydrophilic to bind biological macromolecules, can be effectively wetted, and blots uniformly during sample preparation ${ }^{9}$. So far, two main methods have been described to adhere graphene oxide onto the surface of holey carbon grids: the drop cast method ${ }^{9,10}$ and the surface assembly method ${ }^{11}$. In the drop cast method, a suspension of graphene oxide is directly applied to a glow-discharged grid, allowing it to adhere to the surface before being washed with water and dried. In our hands, this method leads to limited coating of the gird, making it impractical for automated data collection. The surface assembly method works by forming a monolayer film of graphene oxide on the surface of the water, then lowering the water level until the monolayer coats the submerged grids. While this method is effective in coating the grids, the process can be time consuming and requires careful testing of the amount of graphene oxide needed to form a monolayer. 
bioRxiv preprint doi: https://doi.org/10.1101/2021.03.08.434344; this version posted March 8,2021 . The copyright holder for this preprin (which was not certified by peer review) is the author/funder, who has granted bioRxiv a license to display the preprint in perpetuity. It is made available under aCC-BY-NC-ND 4.0 International license.

We have modified the drop cast method to increase the efficiency of graphene oxide adsorption onto the grid surface by coating the grid with polyethyleneimine (PEI) prior to graphene oxide application. This process involves three main steps grid cleaning, PEI treatment, and GO coating - and it takes approximately 30 minutes to make a batch of grids ( 4-12) (Fig. 1A). Since most commercially available grids come with some amount of plastic or other organic contamination, and are relatively hydrophobic out of the box, the surface of the grid must first be cleaned and rendered hydrophilic. To remove any plastic contamination, the surface of the grids is cleaned using an organic solvent (e.g. chloroform). To render the surface of the grids hydrophilic, they are plasma cleaned in a chamber contain low pressure atmospheric air (Fig. 1 figure supplement 1A). The plasma treatment ionizes oxygen in the air, which can then oxidize the surface of the grid, rendering it hydrophilic with a slight negative charge ${ }^{44-48}$. In the second step, the surface of the grid is treated with a buffer solution of PEI, a polycationic polymer. This step allows changing the surface character of the grid so that it has a positive charge capable of attracting negatively charged graphene oxide sheets. We speculate that the reason why graphene oxide does not effectively bind the grid surface without this step is that the two surfaces (plasma cleaned grid and graphene oxide) repel each another as both are negatively charged. In the third and final step, a dilute suspension of graphene oxide sheets is used to coat the surface of the grid.

By coating the glow discharged grid with a layer of a positively charged polymer, like PEI, we were able to significantly increase graphene oxide coating (Fig. 1B). We typically use regularly patterned grids made with a carbon or gold film. We find that we get near complete coating with smaller hole patterns (2/2 or smaller), but larger sizes can also be used. We also find that the most critical part for the success of this protocol is having a good batch of graphene oxide solution. (Fig. 1 - figure supplement 1B).

\section{Particle adsorption of various specimen types}

In order to compare the sample properties of graphene oxide (GO) coated grids with open-hole (OH) or amorphous carbon (AmC) coated grids, we prepared cryo-EM samples of erythrocruorin from Eisenia fetida using suitably pre-treated 1.2/1.3 UltrAuFoil grids. We found that a two-minute incubation time of the sample on the GO and the AmC grids, using $0.08 \mathrm{mg} / \mathrm{mL}$ erythrocruorin $(22 \mathrm{nM})$, resulted in densely packed particles on the grid, with slightly higher density on GO than AmC (Fig 2A-B, Fig. 3A). The open hole grid, on the other hand, required $.8 \mathrm{mg} / \mathrm{mL}$ erythrocruorin (220nM) to achieve roughly a quarter of the particle density seen for GO coated grids under otherwise identical conditions (Fig 2C, Fig. 3A). The need for significantly less sample for $\mathrm{GO}$ (and $\mathrm{AmC}$ ) versus $\mathrm{OH}$ grids has been observed previously ${ }^{11}$ and is likely a result of particles adsorbing to the $\mathrm{GO}$ and the AmC support films.

To ascertain whether the increased number of particles on GO and AmC coated grids is due to adsorption of particles onto the support layer, we collected tomograms for each of the three samples. For the GO and AmC coated grids, most of the particles were bound to the support layer, with the remaining particles bound to the air-water interface (Fig 2A; Fig. 2 figure supplement 1). In stark contrast to the $\mathrm{GO}$ and $\mathrm{AmC}$ coated grids, the $\mathrm{OH}$ grid had all its particles bound to the two air-water interfaces, with a majority of the particles bound to the side away from the blotting paper (Fig 2C; Fig. 2 - figure supplement 1).

The use of support films can significantly increase the particle concentration on the grid, and if GO is used, the background signal added to the images and the resulting contrast loss will be minimal. These properties are particularly useful when the amount of sample is insufficient for the preparation of open-hole grids. An added advantage is that the hydrophilic support can also help to prevent sample damage by constraining particles to the support film and away from the damaging hydrophobic air-water-interface.

\section{Grid tilting with specimen support layers}

For many samples, preferential orientation is a major barrier to obtaining a three-dimensional cryo-EM reconstruction. Even when a reconstruction can be generated, its quality may greatly suffer from anisotropy due to a limited number of views ${ }^{39,49,50}$. Of the various approaches used to increase angular distribution for a cryo-EM sample, tilting is the only one guaranteed to give additional views. However, to achieve high resolution the collection of tilted specimens has been shown to be effective only when the sample is prepared in open holes using gold foil grids that minimize beam-induced motion ${ }^{39}$. To test the effect of having a support layer over the gold foil grid, we collected images at $0^{\circ}$ and $40^{\circ}$ tilts from $\mathrm{OH}, \mathrm{GO}$, and AmC grids (Fig. 3A).

To determine the amount of in-plane $(X Y)$ drift, images were collected with a total exposure of $40 \mathrm{e}-/ \AA^{2}$, fractionated into 40 or 50 frames that were then aligned to measure the amount of drift. Ten images were collected for each condition $(\mathrm{AmC}, \mathrm{GO}$, and $\mathrm{OH})$ at both $0^{\circ}$ and $40^{\circ}$ tilt. The drift between every consecutive pair of frames was then averaged, and the standard deviation plotted (Fig. 3B). For all the images collected at $0^{\circ}$ tilt, the $X Y$ drift was measured to be $\sim 15 \AA$ $(12.8 \AA$ for $\mathrm{GO}, 15.3 \AA$ for $\mathrm{AmC}$, and $17 \AA$ for $\mathrm{OH})$. For the $40^{\circ}$ tilt images, the average drift was approximately double that of the $0^{\circ}$ tilt images for the $\mathrm{GO}(35.3 \AA)$ and $\mathrm{OH}(38.3 \AA)$ grids, but was $\sim 8$ times higher for the $\mathrm{AmC}(120.7 \AA)$ grid.

To determine the potential cause for the increased drift for the AmC grids, we measured the change in defocus over the exposure for the $0^{\circ}$ tilt images (Fig. $3 \mathrm{C}$ ). This was meant to measure the amount of the sample motion in the $\mathrm{Z}$ direction 

available under aCC-BY-NC-ND 4.0 International license.

during the exposure. We found that in images with $\mathrm{GO}$ and $\mathrm{OH}$, there was some amount of fluctuation in the defocus $(\sim \pm 10 \AA)$, but the defocus did not change with dose, while the AmC images increased in defocus by $\sim 100 \AA$ over a total dose of $40 \mathrm{e}-/ \AA^{2}$ exposure. Thus, the large increase in drift for the tilted AmC coated grids can in part be explained by $Z$ motion as reflected in the increase in the defocus seen for these grids. However, given that the change in defocus is $\sim 100 \AA$ and the collected images were tilted $40^{\circ}$, the contribution to the $X Y$ drift would only be $\sim 60 \AA$. The change in defocus also does not explain the increased drift observed in the tilted images for $\mathrm{OH}$ and $\mathrm{GO}$ images, as there is little change in defocus for these samples.

The expected resolution limitation caused by sample drift can be approximated to be equal to the amount of inter-frame drift. Hence, if $1 \AA$ drift occurred during the capture of a single frame, the resolution limit within that frame is limited to $1 \AA$ in the direction of the drift. Therefore, in the case of the AmC grid collected at $40^{\circ}$ tilt, the theoretical resolution limit would be $3 \AA$, given the used collection settings ( $1 \mathrm{e}-/ \AA^{2} /$ frame). However, this is likely optimistic as there is an even greater amount of drift in the earlier frames, when most of the high-resolution information in the sample is yet been reduced due to radiation damage ${ }^{51-53}$. To compensate for the increased drift, more data can be collected, or images can be collected at a faster frame rate so that the drift per frame is reduced. However, the effectiveness of using faster frame rates may be limited as the ability to align images may be reduced due to the consequent lower signal-to-noise ration of the individual frames.

\section{Reconstructions from GO-Au grids}

To test the effectiveness of tilted data collection using GO coated UltrAuFoil grids, we collected a dataset of erythrocruorin at $40^{\circ}$ tilt on a Titan Krios equipped with a K2 Summit direct electron detector mounted behind an energy filter, as described by Tan et al. (Fig. 4) ${ }^{39}$. Initial processing using per-micrograph CTF estimation resulted in a $4.9 \AA$ resolution reconstruction (defocus gradient $\sim 3000 \AA$ ). Correcting the CTF on a per-particle basis improved the resolution to $3.6 \AA \AA$. While the improvement was significant, it should be noted that per-particle CTF estimation does not need to be determined from the start, as this may not be very accurate for some smaller samples. After aberration correction, classification, and polishing, the final resolution obtained was $2.9 \AA$.

The modified GO coating method has been used with several other samples of varying size, and typically resulted in reconstructions with better than $3 \AA$ resolution ${ }^{54}$ (to be published). However, it should be noted that in these other cases, tilting was not required. To demonstrate the capabilities of these GO grids, three other samples were collected: $80 \mathrm{~S}$ yeast ribosome, human apoferritin and the TAF2 subunit of the human transcription factor IID (Fig. 4 - figure supplement 1). A medium sized dataset of $80 \mathrm{~S}$ ribosome, a large (3.2MDa) asymmetric complex, was collected and reconstructed to $2.7 \AA$ resolution globally local resolutions of $2.6 \AA$ for the $60 \mathrm{~S}, 2.9 \AA$ for the $40 \mathrm{~S}$ body, and $3.0 \AA$ for the $40 \mathrm{~S}$ head. A small dataset (266 micrographs) of apoferritin, a medium-sized $(470 \mathrm{kDa})$ rigid and the highly symmetric (octahedral) complex was collected and reconstructed to $2.6 \AA$ resolution. A large dataset (3413 micrographs) of TAF2 (1-985), a small $(110 \mathrm{kDa})$ asymmetric protein, was collected and reconstructed to $2.8 \AA$ resolution.

\section{Conclusion}

In summary, our improved GO grid coating method can be used to rapidly and reliably prepare cryo-EM samples, thus facilitating sample preparation that has the potential to overcome traditional hurdles in cryo-EM studies. Of added value, our method does not require any specialized equipment that would not be found in any typical EM facility. We currently prepare a batch of GO coated grids right before freezing samples, only adding several minutes to normal $\mathrm{OH}$ sample preparation procedures and significantly reducing the required time needed for making coated grids. While we only show three examples of macromolecules solved using these grids, TAF2 represents a typically challenging cryo-EM sample that is small, asymmetric, and dilute. In addition, we have used this procedure to solve larger, more flexible complexes that we were able to refine to high resolution due to our ability to locally refine smaller, flexible regions $(\sim 100 \mathrm{kDa})$ (to be published). Finally, we find that GO-coated gold foil grids can be used to collect tilted data with a drift rate comparable to $\mathrm{OH}$ grids and significantly less than $\mathrm{AmC}$ coated grids. In conclusion, we foresee that our method can help those working with challenging samples that face issues of low-concentration samples, small or flexible complexes, or may be experiencing orientation bias. 
bioRxiv preprint doi: https://doi.org/10.1101/2021.03.08.434344; this version posted March 8,2021 . The copyright holder for this preprint (which was not certified by peer review) is the author/funder, who has granted bioRxiv a license to display the preprint in perpetuity. It is made available under aCC-BY-NC-ND 4.0 International license.

\section{Methods}

\section{Protein purification}

Saccharomyces cerevisiae ribosomes were purified from the CBP flowthrough of a TAP tag purification ${ }^{55}$. The CBP flowthrough was subjected to a $2 \mathrm{~mL} 10-40 \%$ glycerol gradient $(20 \mathrm{mM} H E P E S ~ p H ~ 7.9,150 \mathrm{mM} \mathrm{KCl}, 2 \mathrm{mM} \mathrm{MgCl})$ centrifuged for 16 hours at $35 \mathrm{k} \mathrm{rpm}$ at $4{ }^{\circ} \mathrm{C}$ (Beckman TLS-55). 80S ribosome was found to have formed a pellet at the bottom of the tube and was resuspended in $20 \mathrm{mM} \mathrm{HEPES} \mathrm{pH} 7.9,150 \mathrm{mM} \mathrm{KCl}, 2 \mathrm{mM} \mathrm{MgCl}, 10 \%$ glycerol, aliquoted, flash-frozen in liquid nitrogen, and stored at $-80^{\circ} \mathrm{C}$.

Homo sapiens ferritin (Q8TD27) was recombinantly expressed with an N-terminal GST tag in Escherichia coli. The codonoptimized human ferritin gene was cloned into pET His6-GST TEV LIC Vector (1G) (MacroLab) ${ }^{56}$, transformed into BL21 competent cells, and plated on LB-agar plates containing kanamycin $(50 \mu \mathrm{g} / \mathrm{mL})$. The plates were incubated overnight at $37^{\circ} \mathrm{C}$. A single colony was transferred to a $50 \mathrm{~mL}$ starter culture of Luria-Bertani (LB) broth containing kanamycin (50 $\mu \mathrm{g} / \mathrm{mL}$ ) and grown overnight at $37^{\circ} \mathrm{C}$ with shaking $(220 \mathrm{rpm})$, then used to inoculate two $1 \mathrm{~L}$ flasks of LB with kanamycin $(50 \mu \mathrm{g} / \mathrm{mL})$. Cultures were grown at $37^{\circ} \mathrm{C}$ with shaking $(140 \mathrm{rpm})$ until the optical density at $600 \mathrm{~nm}$ reached 0.4-0.6. The cells were then cooled to $18{ }^{\circ} \mathrm{C}$, and $0.1 \mathrm{mM}$ IPTG was added to induce protein expression. After $12-18 \mathrm{~h}$ of incubation at $18{ }^{\circ} \mathrm{C}$, the cells were harvested by centrifugation at $4 \mathrm{k} \mathrm{rpm}$ for $20 \mathrm{~min}$. The cell pellets were resuspended in PBS and centrifuged at $4 \mathrm{k} \mathrm{rpm}$ for $20 \mathrm{~min}$, then the cell pellets were flash-frozen in liquid nitrogen and stored at $-80^{\circ} \mathrm{C}$. The frozen cell pellets were thawed on ice and resuspended in lysis buffer $(50 \mathrm{mM} \mathrm{HEPES} 7.9,300 \mathrm{mM} \mathrm{NaCl}, 1 \mathrm{mM} \mathrm{MgCl}, 5 \%$ glycerol, one protease inhibitor tablet). The cell suspension was lysed using sonication $10 \mathrm{~s}$ ON / $50 \mathrm{~s}$ OFF for a total processing time of $3 \mathrm{~min}$ at power level 60\% (QSONICA) and subsequently incubated with benzonase for $10 \mathrm{~min}$ at $4{ }^{\circ} \mathrm{C}$ with slow rocking. Cellular debris was removed by centrifugation at $18 \mathrm{k} \mathrm{rpm}$ for $60 \mathrm{~min}$ at $4{ }^{\circ} \mathrm{C}$ (Beckman JA-20). The lysate was incubated with $5 \mathrm{~mL}$ of washed and packed GST resin (GE Healthcare) for 1 hour at $4{ }^{\circ} \mathrm{C}$ with gentle rocking. The resin was poured into a fritted column and the flow-through fraction was collected. The resin was washed with $50 \mathrm{~mL}$ of lysis buffer, then eluted with lysis buffer plus $10 \mathrm{mM}$ glutathione. The elutions were analyzed using SDS-PAGE, and the fractions containing the protein of interest were combined and concentrated to $2 \mathrm{~mL}$ at a final concentration of $3.85 \mathrm{mg} / \mathrm{mL}$ by repeated centrifugation in an Amicon Ultra Centrifugal Filter at $4 \mathrm{k} \mathrm{rpm}$ for $5 \mathrm{~min}$ at $4{ }^{\circ} \mathrm{C}$ (Beckman SX4250). The concentrated protein was incubated overnight with TEV (1:50 mass ratio) with slow rocking at $4{ }^{\circ} \mathrm{C}$ to cleave the $\mathrm{N}$ terminal His6-tag. Following the overnight TEV digest, the combined protein elutions were further concentrated to $0.5 \mathrm{~mL}$ at the same conditions, and SDS-PAGE confirmed the completion of the digest. Potential precipitates were removed from the concentrated protein by centrifugation at $14.2 \mathrm{k} \mathrm{rpm}$ for $5 \mathrm{~min}$ at $4{ }^{\circ} \mathrm{C}$. The digested protein was then loaded onto a Superose 6 10/300 column which was pre-run with the wash buffer (20mM HEPES 7.9, 150mM NaCl). The elutions were analyzed using SDS-PAGE, and the elutions containing the protein of interest were combined, flash-frozen in liquid nitrogen, and stored at $-80^{\circ} \mathrm{C}$.

Homo sapiens TAF2 (1-985) was recombinantly expressed with an N-terminal MBP tag in Trichoplusia ni High Five cells.

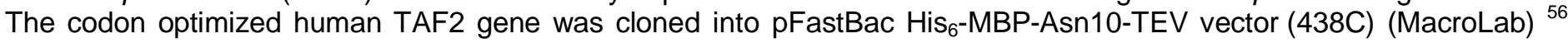
and transformed into DH10 MultiBac competent cells to generate bacmids for baculovirus production. Purified bacmids were transfected into Spodoptera frugiperda Sf9 cells using FuGene transfection reagent and amplified for a further two rounds before being used to infect $500 \mathrm{~mL}$ cultures of High Five cells for protein production. High Five cells were grown for 60 hours post-infection at $28 \square^{\circ} \mathrm{C}$, were then harvested by centrifugation, washed in PBS, flashed frozen, and stored at -80 ${ }^{\circ} \mathrm{C}$. Pellets were resuspended in lysis buffer $(50 \mathrm{mM}$ HEPES pH 7.9, $500 \square \mathrm{mM} \mathrm{NaCl}, 2 \mathrm{mM} \mathrm{MgCl} 2,10 \%$ glycerol and lysed by sonication (10s ON / 50s OFF for a total processing time of $3 \mathrm{~min}$ at power level $50 \%$ ) and subsequently incubated with benzonase for $10 \mathrm{~min}$ at $4{ }^{\circ} \mathrm{C}$ with slow rocking. Cellular debris was removed by centrifugation at $18 \mathrm{k}$ rpm for $60 \mathrm{~min}$ at 4 ${ }^{\circ} \mathrm{C}$. Clarified lysate was then passed over $2 \mathrm{~mL}$ of packed Ni-NTA resin and washed with lysis buffer before being eluted with lysis buffer containing $250 \mathrm{mM}$ imidazole. Elutions were pooled and incubated with $1 \mathrm{~mL}$ of amylose resin overnight. Amylose resin was subsequently washed with lysis buffer and eluted with lysis buffer with $20 \mathrm{mM}$ maltose. The elution was then TEV digested overnight, and the digest was incubated with $.25 \mathrm{~mL}$ of Ni-NTA resin. The flow-through of the Ni-NTA resin containing TAF2 was loaded onto an Superdex 200 3.2/300 and run using lysis buffer. Fractions containing pure TAF2 were pooled and concentrated to $4 \mu \mathrm{M}$, flash-frozen in liquid nitrogen and stored at $-80^{\circ} \mathrm{C}$.

\section{Graphene oxide grid preparation}

Graphene oxide coating was performed on 1.2/1.3 holey patterned carbon or gold film grids (Protochips or Quantifoil). To wash them, grids were placed face-up on a piece of filter paper in a glass dish. A drop of chloroform was added to the top of each grid and allowed to dry; this was repeated once more. The grids were then placed in a small glass petri dish lined with a stainless steel mesh and glow discharged in either a Solarus plasma cleaner (10s, 5W, 80mTorr), Cressington Sputter coater (30s, 15mA, .04 mBar), or Tergeo plasma cleaner (60s, 15W, 210mTorr) in a chamber filled with residual air. The grids were then picked up using an anti-capillary tweezer, and $4 \mathrm{uL}$ of $1 \mathrm{mg} / \mathrm{mL}$ PEI (Polyethylenimine $\mathrm{HCl} \mathrm{MAX}$ Linear 40K from Polysciences Catalog No. 24765-1 - the higher the molecular weight of the polymer, the better it stays adhered to the grid during subsequent wash steps) buffered in $25 \mathrm{mM}$ HEPES pH 7.0 (the buffer was prepared fresh before being applied to the grids by mixing $4 \mathrm{uL} 10 \mathrm{mg} / \mathrm{mL}$ PEI with $36 \mathrm{uL} 27.78 \mathrm{mM} \mathrm{HEPES} \mathrm{pH} \mathrm{7.9)} \mathrm{was} \mathrm{applied} \mathrm{to} \mathrm{the} \mathrm{top}$ 
bioRxiv preprint doi: https://doi.org/10.1101/2021.03.08.434344; this version posted March 8,2021 . The copyright holder for this preprint (which was not certified by peer review) is the author/funder, who has granted bioRxiv a license to display the preprint in perpetuity. It is made available under aCC-BY-NC-ND 4.0 International license.

of the grid. The drop was incubated on the grid for 2 minutes and blotted off with a filter paper, and washed twice by adding a $4 \mathrm{uL}$ of water on top of the grid and blotting off (first water wash was added to the top of the grid as soon as possible to avoid letting the PEI drop residue from drying on the grid). The grid was returned to a glass petri dish lined with filter paper to dry (at least 2 minutes). The grids were then picked up using anti-capillary tweezers, and a 4uL drop of $.2 \mathrm{mg} / \mathrm{mL}$ GO (Graphene Oxide dispersion at $2 \mathrm{mg} / \mathrm{mL}$ Sigma-Aldrich $763705-25 \mathrm{ML}$; the suspension aggregates with time, we typically replace our stock every $\sim 1-3$ years when we start observing clumps in the suspension) diluted in water and clarified by centrifugation at $1500 \mathrm{~g}$ for 1 minute was applied to the top of the grid. The drop was incubated on the grid for 2 minutes and blotted away with a filter paper (we slide the filter while blotting to prevent clogging the filter paper, then continue to the next water wash as fast as possible to avoid the excess GO flakes from drying on the grid surface). We wash twice by adding a $4 \mathrm{uL}$ of water on top of the grid and then blot the water off. The grid is then returned to a glass petri dish lined with filter paper and let dry (at least 2 minutes) before using. Grids were typically used an hour after being prepared and always used the same day, as grids tend to become hydrophobic over time. If GO over coverage is observed, the power of the glow discharge should be reduced or additional water washes after GO application performed; conversely, if coverage is insufficient, glow discharge power should be increased or a lower GO dilution should be used for grid application.

\section{Cryo-EM sample preparation}

For open hole cryo-EM sample preparation, grids were first washed with chloroform, dried, and glow discharged in a Solarus plasma cleaner for $20 \mathrm{~s}$ at $5 \mathrm{~W}$ and $80 \mathrm{mTorr}$. For sample freezing, $4 \mathrm{uL}$ of erythrocruorin at $0.8 \mathrm{mg} / \mathrm{mL}$ was added to the grid at $4{ }^{\circ} \mathrm{C}$ under $100 \%$ humidity in a Mark IV Vitrobot (FEI), blotted with a Whatman \#1 for 3 sec at $5 \mathrm{~N}$ force and then immediately plunged into liquid ethane cooled by liquid nitrogen.

To prepare AmC coated grids, grids were washed with chloroform and then coated with a layer of thin carbon 2nm thick. Grids were then glow discharged in a Solarus plasma cleaner for 10 s at $5 \mathrm{~W}$ and $80 \mathrm{mTorr}$. For sample freezing, $4 \mathrm{uL}$ of erythrocruorin as $0.08 \mathrm{mg} / \mathrm{mL}$ was added to the grid and incubated for 2 minutes at $4{ }^{\circ} \mathrm{C}$ under $100 \%$ humidity in a Mark IV Vitrobot (FEI), blotted with a Whatman \#1 for $2.5 \mathrm{sec}$ at $0 \mathrm{~N}$ force and then immediately plunged into liquid ethane cooled by liquid nitrogen.

GO coated grids were prepared as described in the section above, and the freezing conditions were the same as AmC coated grids. For $80 \mathrm{~S}$ ribosome (unknown concentration) the sample was incubated for 5 minutes, for apoferritin $(0.1 \mathrm{mg} / \mathrm{mL} ; 210 \mathrm{nM})$ the sample was incubated for 1 minute and for TAF2 $(0.22 \mathrm{mg} / \mathrm{mL} ; 2 \mathrm{uM})$ the sample was incubated for 3 minutes.

\section{Cryo-EM data collection}

For Fig 1, grids were transferred to a 626 Cryo-Transfer Holder (Gatan) and loaded into an F20 electron microscope (FEI) operated at $120 \mathrm{keV}$ and equipped with a Gatan Ultrascan 4k x 4k CCD camera, and data was collected with Leginon ${ }^{57}$. High magnification images were collected with a pixel size of $2.29 \AA /$ pix.

For Figs 2 and 3, grids were loaded into a Talos Arctica electron microscope (Thermo Fisher Scientific) operated at 200 keV acceleration voltage and equipped with a K3 direct electron detector (Gatan) operated in super-resolution mode. Data were collected with SerialEM ${ }^{58}$. For tomograms, a bidirectional tilt scheme was used starting at $-20^{\circ}$ to $+59^{\circ}$ and then $-23^{\circ}$ to $-57^{\circ}$ with a $3^{\circ}$ angular step size. Each tilt was collected at $-3 \mu \mathrm{m}$ defocus at a pixel size of $1.12 \AA$ pix and a total dose of $3 \mathrm{e}-/ \AA^{2}$. For Fig 3, images were collected at $0^{\circ}$ and $40^{\circ}$ with a pixel size of $1.12 \AA$ ipix for a total dose of $40 \mathrm{e}-/ \AA^{2}$. For $\mathrm{AmC}$ and $\mathrm{OH}$ grids, movies were collected with 50 frames, and for the $\mathrm{GO}$ grid, the movies were collected with 40 frames.

For Fig 4, erythrocruorin grids were loaded into a Titan Krios electron microscope (FEl) operated at $300 \mathrm{keV}$ and equipped with a K2 Summit direct electron detector mounted behind an energy filter (Gatan) operated in super-resolution mode and data was collected with SerialEM ${ }^{58}$. Images were collected at $40^{\circ}$ tilt at a pixel size of $0.90 \AA /$ pix with a total dose of $40 \mathrm{e}-/ \AA^{2}$. 80S ribosome, apoferritin and TAF2 grids were loaded into a Talos Arctica electron microscope (FEI) operated at $200 \mathrm{keV}$ and equipped with a K3 direct electron detector (Gatan) operated in super-resolution mode and data was collected with SerialEM ${ }^{58}$. For $80 \mathrm{~S}$ ribosome images were collected at a pixel size of $1.12 \AA /$ pix with a total dose of $40 \mathrm{e}-/ \AA^{2}$ and for apoferritin and TAF2 images were collected at a pixel size of .69 $\AA /$ pix with a total dose of $40 \mathrm{e}-/ \AA^{2}$.

\section{Cryo-EM data processing}

The tomographic reconstructions shown in Fig 2 were performed in IMOD ${ }^{59}$ using the automated patch tracking procedure. Tomographic volumes were reconstructed using five iterations of SIRT and binned 8-fold for visualization.

Motion correction of the images shown in Fig 3 was performed using motioncor2 ${ }^{60}$, CTF estimation was done with GCTF

61. $X Y$ drift was measured by calculating the Euclidean distance between frame shifts as outputted from motioncor2. The distances were summed up for each exposure count. Using ten micrographs, the total drift for each exposure count was used to calculate the mean value and standard deviation. Z change (using defocus change) was measured by calculating 
bioRxiv preprint doi: https://doi.org/10.1101/2021.03.08.434344; this version posted March 8, 2021. The copyright holder for this preprin (which was not certified by peer review) is the author/funder, who has granted bioRxiv a license to display the preprint in perpetuity. It is made available under aCC-BY-NC-ND 4.0 International license.

the defocus of a rolling average of aligned and summed frames. The number of frames to use was determined by testing different rolling averages for each sample type. For AmC images, a rolling average of 5 frames with a exposure of $4 \mathrm{e}-/ \AA^{2}$ was used, for GO images a rolling average of 7 frame with a exposure of $7 \mathrm{e}-/ \AA^{2}$ was used, and for $\mathrm{OH}$ images a rolling average of 9 frame with a exposure of $7.2 \mathrm{e}-/ \AA^{2}$ was use. The defocus from the first frame set was subtracted from all frames sets to establish the same start point for all images. Using ten micrographs, each corresponding frame set was used to calculate the mean value and standard deviation.

Eythrocruorin data (Fig 4, Fig 3 - figure supplement 1) were motion-corrected with motioncor2 ${ }^{60}$, CTF estimation was done with GCTF ${ }^{61}$, and particles were picked using Gautomatch (version 0.53, from K. Zhang, MRC-LMB, Cambridge). Processing was done in Relion3.0 ${ }^{62}$. Initially, motion correction was performed with $5 \times 5$ patch correction, and CTF estimation was done on the whole micrograph. The initial set of 113,792 particles was subjected to 2D classification, and 46591 particles were selected for the initial model generated with $\mathrm{C} 1$ symmetry. This initial model was used as initial reference for refinement with D6 symmetry, which went to $4.9 \AA$ resolution. Per-particle CTF and astigmatism values were refined, and beam tilt correction was measured and corrected for, resulting in an improved resolution of $3.2 \AA{ }^{62}$. The particles were then subjected to $3 \mathrm{D}$ classification without alignment, from which a single class was selected containing 30,254 particles. Refinement of this subset of particles led to a resolution of to $3 \AA$ that improved to $2.9 \AA$ after polishing ${ }^{63}$. $80 \mathrm{~S}$ ribosome, apoferritin and TAF2 data was motion corrected using motioncor ${ }^{60}$, CTF estimation was done with GCTF ${ }^{61}$, and particles were picked using Relion LoG picker ${ }^{62}$. Processing was done in Relion3.0 ${ }^{62}$. Initially, motion correction was performed with $1 \times 1$ patch correction, and CTF estimation was done on the whole micrograph. Particles were subjected to 2D and 3D classification to select the best particles, followed by initial model generation, 3D refinement, CTF refinement, polishing ${ }^{63}$, and alignment-free $3 D$ classification. The final set of apoferritin particles was refined to $2.6 \AA$ and the final set of TAF2 particles was refined to $2.8 \AA \AA$. $80 \mathrm{~S}$ ribosome refinement was subjected to multibody refinement ${ }^{64}$ with to locally refine the $60 \mathrm{~S}(2.7 \AA)$, $40 \mathrm{~S}$ body $(2.9 \AA)$ and $40 \mathrm{~S}$ head $(3.0 \AA)$. All local resolution calculations were done using Relion ${ }^{62}$.

Acknowledgements: Most of the data was collected at the Cal-Cryo facility. We thank Robert Louder for providing Eisenia fetida erythrocruorin; Patricia Grob, Robert Louder, Ben LaFrance, Vignesh Kasinath, and Basil Greber for discussion; Patricia Grob for electron microscopy support; Abhiram Chintangal and Paul Tobias for computing support; Patricia Grob and Giho Park for feedback on GO prep method; Robert Louder, Basil Greber, Vignesh Kasinath and Yuan $\mathrm{He}$ for comments on the manuscript. Images of cryo-EM reconstructions were generated using UCSF ChimeraX ${ }^{65,66}$ (developed by UCSF RBVI with support from NIH R01-GM129325, OCICB and NIAID).

Funding: This work was funded through NIGMS grant R01-GM63072 to E.N. A.B.P. was partially supported by an NIGMS Molecular Biophysics Training Grant (GM008295). E.N. is a Howard Hughes Medical Institute investigator.

Author Contributions: A.L. purified apoferritin and A.B.P purified TAF2. A.B.P devised a modified GO coating protocol and prepared, collected, processed, and analyzed cryo-EM data. A.B.P. D.T. assisted in tomogram collection. A.B.P wrote the paper with input from other authors. 
bioRxiv preprint doi: https://doi.org/10.1101/2021.03.08.434344; this version posted March 8, 2021. The copyright holder for this preprint (which was not certified by peer review) is the author/funder, who has granted bioRxiv a license to display the preprint in perpetuity. It is made available under aCC-BY-NC-ND 4.0 International license.

\section{References}

1. Nogales, E. \& Scheres, S. H. W. H. W. Cryo-EM: A Unique Tool for the Visualization of Macromolecular Complexity Title. 58, (2015).

2. Cheng, Y., Grigorieff, N., Penczek, P. A. \& Walz, T. A primer to single-particle cryo-electron microscopy. Cell 161, 438-449 (2015).

3. Williams, R. C. \& Glaeser, R. M. Ultrathin carbon support films for electron microscopy. Science (80-. ). 175, 10001001 (1972).

4. Pantelic, R. S. et al. Graphene: Substrate preparation and introduction. (2010). doi:10.1016/j.jsb.2010.10.002

5. Russo, C. J. \& Passmore, L. A. Controlling protein adsorption on graphene for cryo-EM using low-energy hydrogen plasmas. Nat. Methods 11, 649-652 (2014).

6. D'Imprima, E. et al. Protein denaturation at the air-water interface and how to prevent it. Elife 8, (2019).

7. Zhang, J. et al. Clean Transfer of Large Graphene Single Crystals for High-Intactness Suspended Membranes and Liquid Cells. Adv. Mater. 29, 1700639 (2017).

8. Liu, N. et al. Bioactive Functionalized Monolayer Graphene for High-Resolution Cryo-Electron Microscopy. (2019). doi:10.1021/jacs.8b13038

9. Pantelic, R. S., Meyer, J. C., Kaiser, U., Baumeister, W. \& Plitzko, J. M. Graphene oxide: A substrate for optimizing preparations of frozen-hydrated samples. J. Struct. Biol. 170, 152-156 (2010).

10. Bokori-Brown, M. et al. Cryo-EM structure of lysenin pore elucidates membrane insertion by an aerolysin family protein. Nat. Commun. 7, 11293 (2016).

11. Palovcak, E. et al. A simple and robust procedure for preparing graphene-oxide cryo-EM grids. J. Struct. Biol. 204, 80-84 (2018).

12. Medalia, O. et al. Cryoelectron microscopy and cryoelectron tomography of the nuclear pre-mRNA processing machine. J. Struct. Biol. 138, 74-84 (2002).

13. Kelly, D. F., Dukovski, D. \& Walz, T. Monolayer purification: A rapid method for isolating protein complexes for single-particle electron microscopy. Proc. Natl. Acad. Sci. 105, 4703-4708 (2008).

14. Stark, H. GraFix: Stabilization of Fragile Macromolecular Complexes for Single Particle Cryo-EM. Methods Enzymol. 481, 109-126 (2010).

15. Haloupek, N., Grob, P., Tenthorey, J., Vance, R. E. \& Nogales, E. Cryo-EM studies of NAIP-NLRC4 inflammasomes. in Methods in Enzymology 625, 177-204 (Academic Press Inc., 2019).

16. Wang, F. et al. General and robust covalently linked graphene oxide affinity grids for high-resolution cryo-EM. doi:10.1101/657411

17. Yu, G., Li, K. \& Jiang, W. Antibody-based affinity cryo-EM grid. Methods 100, 16-24 (2016).

18. Han, B. G. et al. Electron microscopy of biotinylated protein complexes bound to streptavidin monolayer crystals. J. Struct. Biol. 180, 249-253 (2012).

19. Darst, S. A. et al. Two-dimensional crystals of streptavidin on biotinylated lipid layers and their interactions with biotinylated macromolecules. Biophys. J. 59, 387-396 (1991).

20. Snijder, J. et al. Vitrification after multiple rounds of sample application and blotting improves particle density on cryo-electron microscopy grids. J. Struct. Biol. 198, 38-42 (2017).

21. Meyerson, J. R. et al. Self-assembled monolayers improve protein distribution on holey carbon cryo-EM supports. Sci. Rep. 4, 7084 (2015).

22. Shen, P. S. et al. Rqc2p and $60 \mathrm{~S}$ ribosomal subunits mediate mRNA-independent elongation of nascent chains. Science (80-. ). 347, 75-78 (2015).

23. Noble, A. J. et al. Routine single particle CryoEM sample and grid characterization by tomography. Elife 7, (2018).

24. Chen, J., Noble, A. J., Kang, J. Y. \& Darst, S. A. Eliminating effects of particle adsorption to the air/water interface 
bioRxiv preprint doi: https://doi.org/10.1101/2021.03.08.434344; this version posted March 8,2021 . The copyright holder for this preprint (which was not certified by peer review) is the author/funder, who has granted bioRxiv a license to display the preprint in perpetuity. It is made available under aCC-BY-NC-ND 4.0 International license.

in single-particle cryo-electron microscopy: Bacterial RNA polymerase and CHAPSO. J. Struct. Biol. X 1, 100005 (2019).

25. Chari, A. et al. ProteoPlex: Stability optimization of macromolecular complexes by sparse-matrix screening of chemical space. Nat. Methods 12, 859-865 (2015).

26. De Carlo, Adrian, Kälin, Mayer \& Dubochet. Unexpected property of trehalose as observed by cryo-electron microscopy. J. Microsc. 196, 40-45 (1999).

27. D'Imprima, E. et al. Protein denaturation at the air-water interface and how to prevent it. Elife 8, (2019).

28. Han, B.-G., Watson, Z., Cate, J. H. D. \& Glaeser, R. M. Monolayer-crystal streptavidin support films provide an internal standard of cryo-EM image quality. J. Struct. Biol. 200, 307-313 (2017).

29. Noble, A. J. et al. Reducing effects of particle adsorption to the air-water interface in cryo-EM. Nat. Methods 15, 793-795 (2018).

30. Zhang, J. et al. Mechanism of folding chamber closure in a group II chaperonin. Nature 463, 379-383 (2010).

31. Zhao, M. et al. Mechanistic insights into the recycling machine of the SNARE complex. Nature 518, 61-67 (2015).

32. Fernandez-Leiro, R., Conrad, J., Scheres, S. H. W. \& Lamers, M. H. Cryo-EM structures of the E. Coli replicative DNA polymerase reveal its dynamic interactions with the DNA sliding clamp, exonuclease and T. Elife 4, (2015).

33. Naydenova, K., Peet, M. J. \& Russo, C. J. Multifunctional graphene supports for electron cryomicroscopy. Proc. Natl. Acad. Sci. U. S. A. 116, 11718-11724 (2019).

34. Nguyen, T. H. D. et al. The architecture of the spliceosomal U4/U6.U5 tri-snRNP. Nature 523, 47-52 (2015).

35. Da Fonseca, P. C. A. \& Morris, E. P. Cryo-EM reveals the conformation of a substrate analogue in the human $20 \mathrm{~S}$ proteasome core. Nat. Commun. 6, 1-6 (2015).

36. Patel, A. B. et al. Structure of human TFIID and mechanism of TBP loading onto promoter DNA. Science 362, eaau8872 (2018).

37. Lander, G. C. et al. Complete subunit architecture of the proteasome regulatory particle. Nature 482, 186-191 (2012).

38. Liu, Y., Meng, X. \& Liu, Z. Deformed grids for single-particle cryo-electron microscopy of specimens exhibiting a preferred orientation. J. Struct. Biol. 182, 255-258 (2013).

39. Tan, Y. Z. et al. Addressing preferred specimen orientation in single-particle cryo-EM through tilting. Nat. Methods 14, 793-796 (2017).

40. Naydenova, K. et al. Structure of the SARS-CoV-2 RNA-dependent RNA polymerase in the presence of favipiravirRTP. Proc. Natl. Acad. Sci. 118, e2021946118 (2021).

41. Russo, C. J. \& Passmore, L. A. Ultrastable gold substrates for electron cryomicroscopy. Science (80-. ). 346, $1377-1380$ (2014).

42. Beckert, B. et al. Structure of a hibernating 100S ribosome reveals an inactive conformation of the ribosomal protein S1. Nat. Microbiol. 3, 1115-1121 (2018).

43. Zhao, H. et al. Structure of mammalian Mediator complex reveals Tail module architecture and interaction with a conserved core. Nat. Commun. 12, 1355 (2021).

44. Ron, H., Matlis, S. \& Rubinstein, I. Self-Assembled Monolayers on Oxidized Metals. 2. Gold Surface Oxidative Pretreatment, Monolayer Properties, and Depression Formation. Langmuir 14, 1116-1121 (1998).

45. Widdascheck, F., Kothe, M., Hauke, A. A. \& Witte, G. The effect of oxygen plasma treatment of gold electrodes on the molecular orientation of CuPc films. Appl. Surf. Sci. 507, 145039 (2020).

46. Fuchs, P. Low-pressure plasma cleaning of Au and PtIr noble metal surfaces. Appl. Surf. Sci. 256, 1382-1390 (2009).

47. Tsai, H. et al. Instability of gold oxide Au2O3. Surf. Sci. 537, L447-L450 (2003).

48. Koslowski, B. et al. Oxidation of preferentially (1 111 )-oriented Au films in an oxygen plasma investigated by 
bioRxiv preprint doi: https://doi.org/10.1101/2021.03.08.434344; this version posted March 8,2021 . The copyright holder for this preprin (which was not certified by peer review) is the author/funder, who has granted bioRxiv a license to display the preprint in perpetuity. It is made available under aCC-BY-NC-ND 4.0 International license.

scanning tunneling microscopy and photoelectron spectroscopy. Surf. Sci. 475, 1-10 (2001).

49. Baldwin, P. R. \& Lyumkis, D. Non-Uniformity of Projection Distributions Attenuates Resolution in Cryo-EM. bioRxiv (2019). doi:10.1101/635938

50. Naydenova, K. \& Russo, C. J. Measuring the effects of particle orientation to improve the efficiency of electron cryomicroscopy. Nat. Commun. 8, 629 (2017).

51. Taylor, K. A. \& Glaeser, R. M. Electron microscopy of frozen hydrated biological specimens. J. Ultrasructure Res. 55, 448-456 (1976).

52. Scheres, S. H. w. Beam-induced motion correction for sub-megadalton cryo-EM particles. Elife 3, e03665 (2014).

53. Grant, T. \& Grigorieff, N. Measuring the optimal exposure for single particle cryo-EM using a $2.6 \AA$ A reconstruction of rotavirus VP6. Elife 4, (2015).

54. Herbst, D. A. et al. Structure of the human SAGA coactivator complex The divergent architecture of human SAGA allows modular coordination of transcription activation and co-transcriptional splicing. bioRxiv 2021.02.08.430339 (2021). doi:10.1101/2021.02.08.430339

55. Puig, O. et al. The tandem affinity purification (TAP) method: A general procedure of protein complex purification. Methods 24, 218-229 (2001).

56. Gradia, S. D. et al. MacroBac: New Technologies for Robust and Efficient Large-Scale Production of Recombinant Multiprotein Complexes. in Methods in Enzymology 592, 1-26 (Academic Press Inc., 2017).

57. Suloway, C. et al. Automated molecular microscopy: The new Leginon system. J. Struct. Biol. 151, 41-60 (2005).

58. Schorb, M., Haberbosch, I., Hagen, W. J. H., Schwab, Y. \& Mastronarde, D. N. Software tools for automated transmission electron microscopy. Nat. Methods 16, 471-477 (2019).

59. Kremer, J. R., Mastronarde, D. N. \& Mclntosh, J. R. Computer visualization of three-dimensional image data using IMOD. J. Struct. Biol. 116, 71-76 (1996).

60. Zheng, S. Q. et al. MotionCor2: anisotropic correction of beam-induced motion for improved cryo-electron microscopy. Nat. Methods 14, 331-332 (2017).

61. Zhang, K. Gctf: Real-time CTF determination and correction. J. Struct. Biol. 193, 1-12 (2016).

62. Zivanov, J. et al. New tools for automated high-resolution cryo-EM structure determination in RELION-3. Elife 7, (2018).

63. Zivanov, J., Nakane, T. \& Scheres, S. H. W. A Bayesian approach to beam-induced motion correction in cryo-EM single-particle analysis. IUCrJ 6, 5-17 (2019).

64. Nakane, T., Kimanius, D., Lindahl, E. \& Scheres, S. H. Characterisation of molecular motions in cryo-EM singleparticle data by multi-body refinement in RELION. Elife 7, (2018).

65. Goddard, T. D. et al. UCSF ChimeraX: Meeting modern challenges in visualization and analysis. Protein Sci. 27, 14-25 (2018).

66. Pettersen, E. F. et al. UCSF ChimeraX: Structure visualization for researchers, educators, and developers. Protein Sci. 30, 70-82 (2021). 
bioRxiv preprint doi https://doi.org/10.1101/2021.03.08.434344 this version posted March 8, 2021. The copyright holder for this preprint (which was not certified by peer review) is the author/funder, who has granted bioRxiv a license to display the preprint in perpetuity. It is made available under aCC-BY-NC-ND 4.0 International license.

A

$$
\text { Step 1: }
$$

Step 2:

Step 3:

Wash $1.2 / 1 / 3$ holey patterned grids with organic solvent (to disolve contaminants), and glow discharge grid (to render grid hydrophilic).

Coat surface with PEI (to give the Adhere GO sheets (to cover holes).

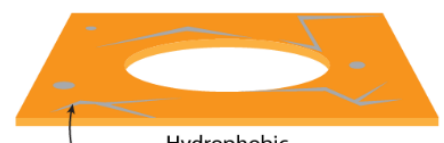

Hydrophobic

Hydrophobic organic hydrocarbons, plastics, etc.)

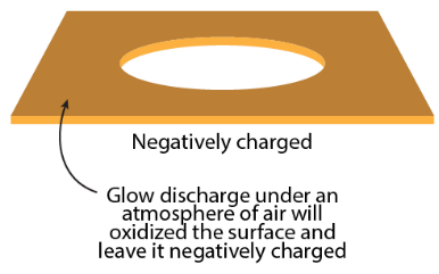

B

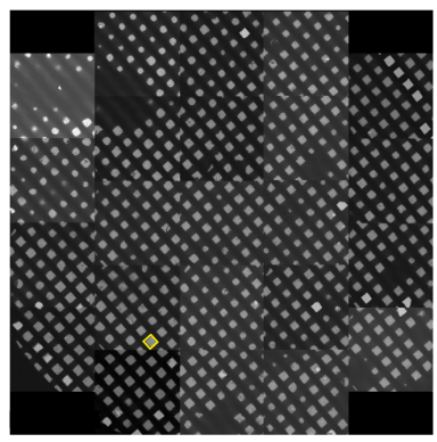

Grid Atlas

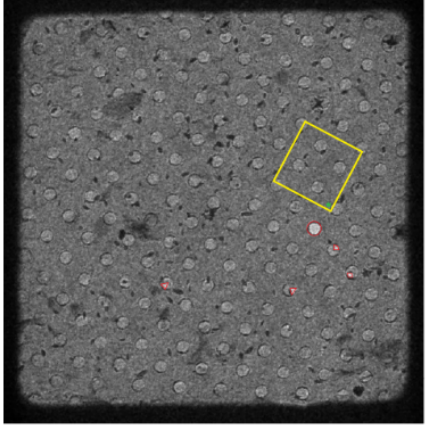

Square Map

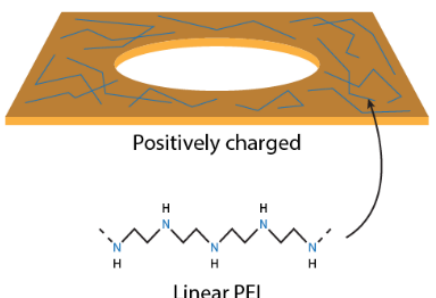

Linear PEI

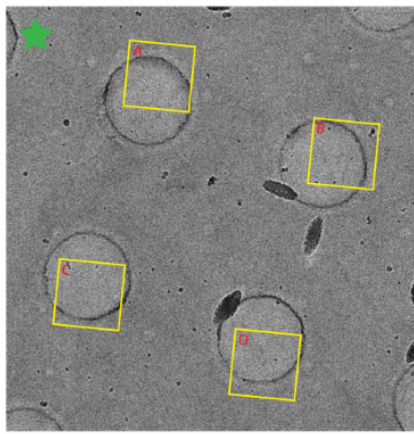

Hole View

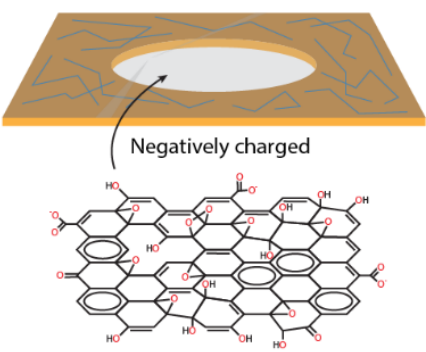

Graphene Oxide
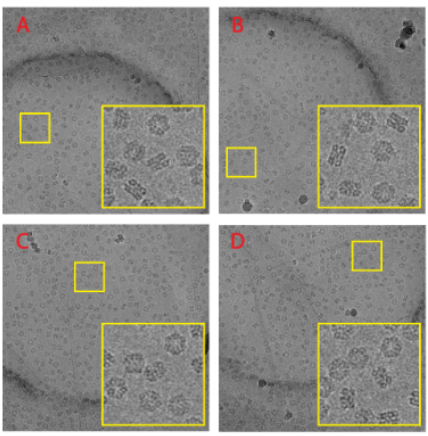

Exposures

Figure 1 | Modified graphene oxide coating method.

A. Holey patterned grid preparation and coating workflow. The grids are first washed with organic solvent (i.e., chloroform) and then glow discharged in a chamber contain low pressure atmospheric air. The grids are then coated with a polycationic polymer (i.e., PEI). Finally, the grids are coated with GO sheets to cover the holes.

B. Example of a GO coated grid at several magnifications. The yellow squares indicate the region magnified in the image to the left, or the inset for the right-most panel. 
bioRxiv preprint doi: https://doi.org/10.1101/2021.03.08.434344; this version posted March 8, 2021. The copyright holder for this preprint (which was not certified by peer review) is the author/funder, who has granted bioRxiv a license to display the preprint in perpetuity. It is made available under aCC-BY-NC-ND 4.0 International license.

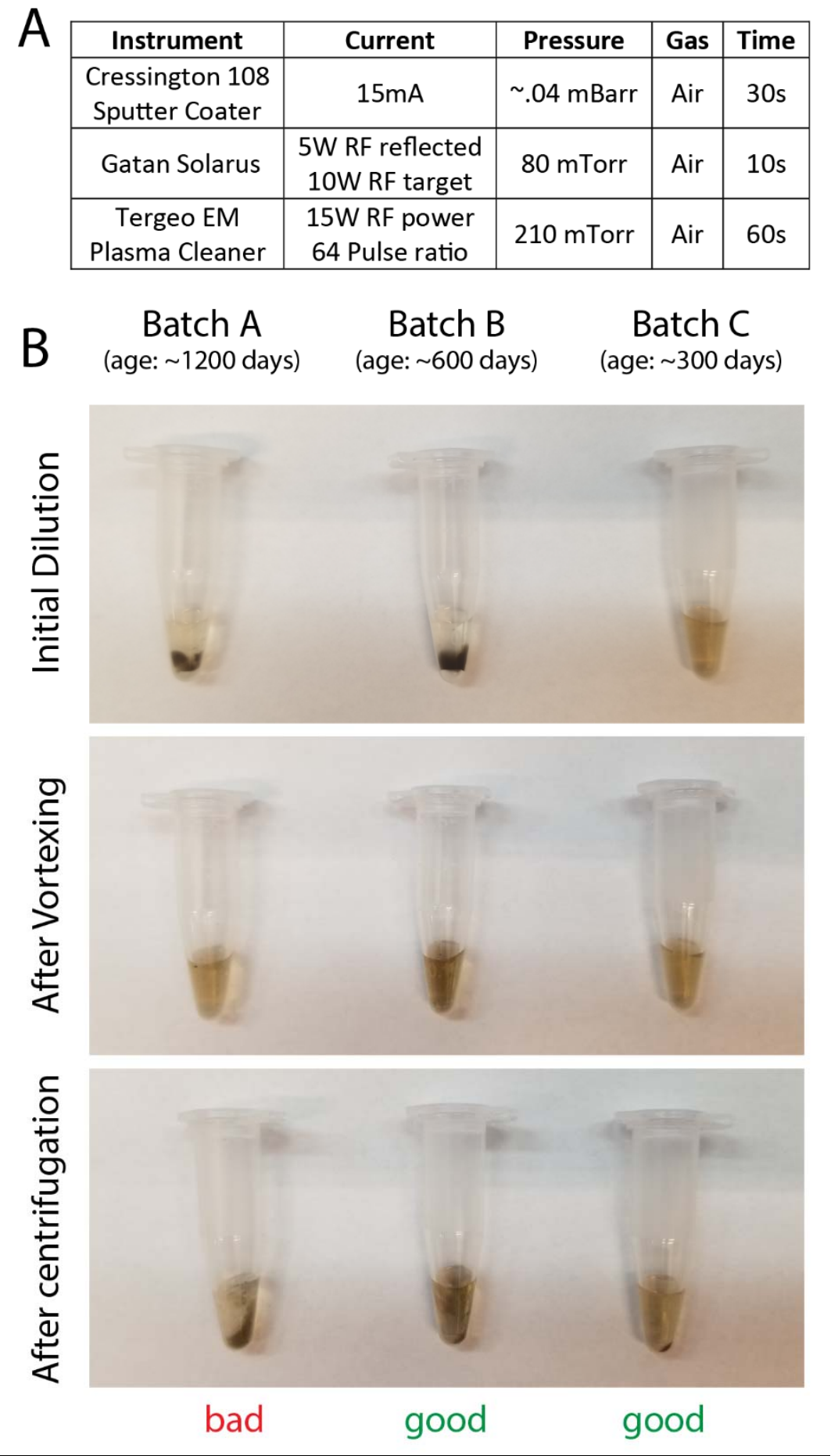

Figure 1 - Figure Supplement 1 | Grid preparation settings.

A. Recommended glow discharge settings

B. Graphene oxide dispersions batch and age variations (2mg/mL Sigma-Aldrich $763705-25 \mathrm{ML})$ 
bioRxiv preprint doi: https://doi.org/10.1101/2021.03.08.434344; this version posted March 8, 2021. The copyright holder for this preprint (which was not certified by peer review) is the author/funder, who has granted bioRxiv a license to display the preprint in perpetuity. It is made available under aCC-BY-NC-ND 4.0 International license.

A

Amorphous Carbon
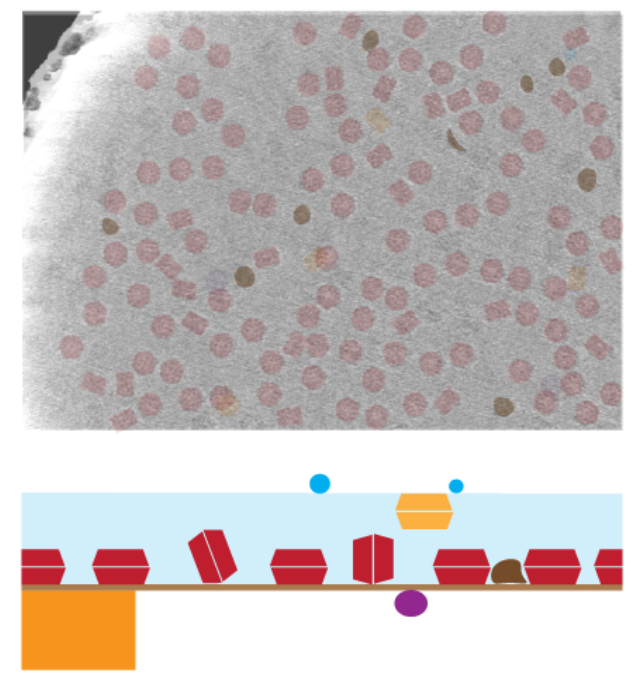

B

\section{Graphene Oxide}
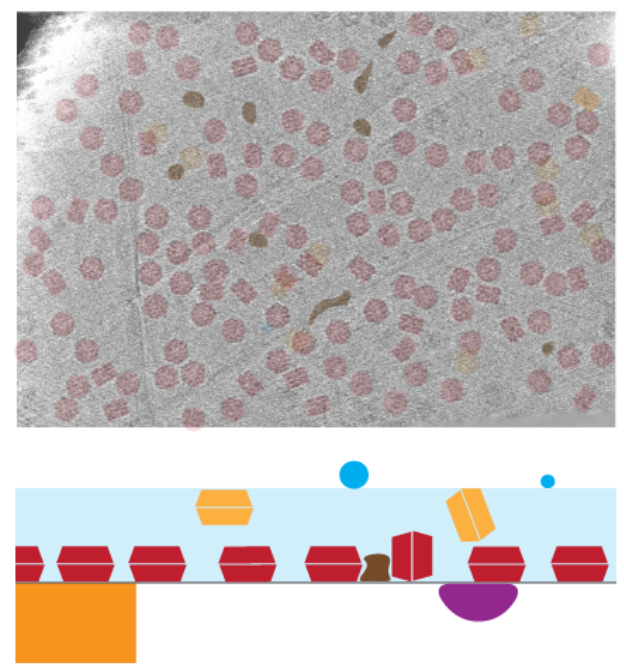

C

Open hole
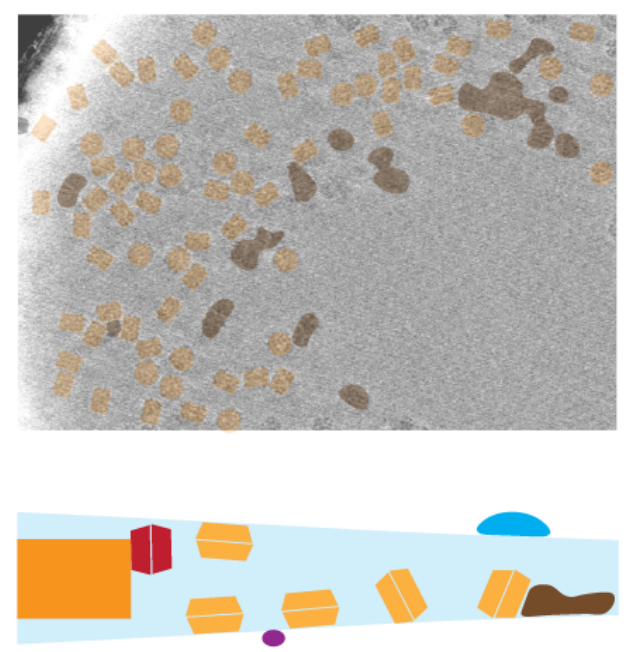

Figure 2 | Particle positions on different grid types.

Projections in the Z-direction of tomographic reconstructions with segmented particles for samples prepared on (A) amorphous carbon, (B) graphene oxide and (C) open hole grids (top), with cartoon representations of the grids that illustrate how the particles were distributed in the vitreous ice layer (bottom). Particles are colored based on their distance from the lower surface: red - particles bound to support layer, orange - particles bound to air-water-interface, blue/purple crystalline ice on top or bottom of the vitreous ice layer, brown - damaged and aggregated complexes. 
bioRxiv preprint doi: https://doi.org/10.1101/2021.03.08.434344; this version posted March 8, 2021. The copyright holder for this preprint (which was not certified by peer review) is the author/funder, who has granted bioRxiv a license to display the preprint in perpetuity. It is made available under aCC-BY-NC-ND 4.0 International license.

\section{Amorphous Carbon}
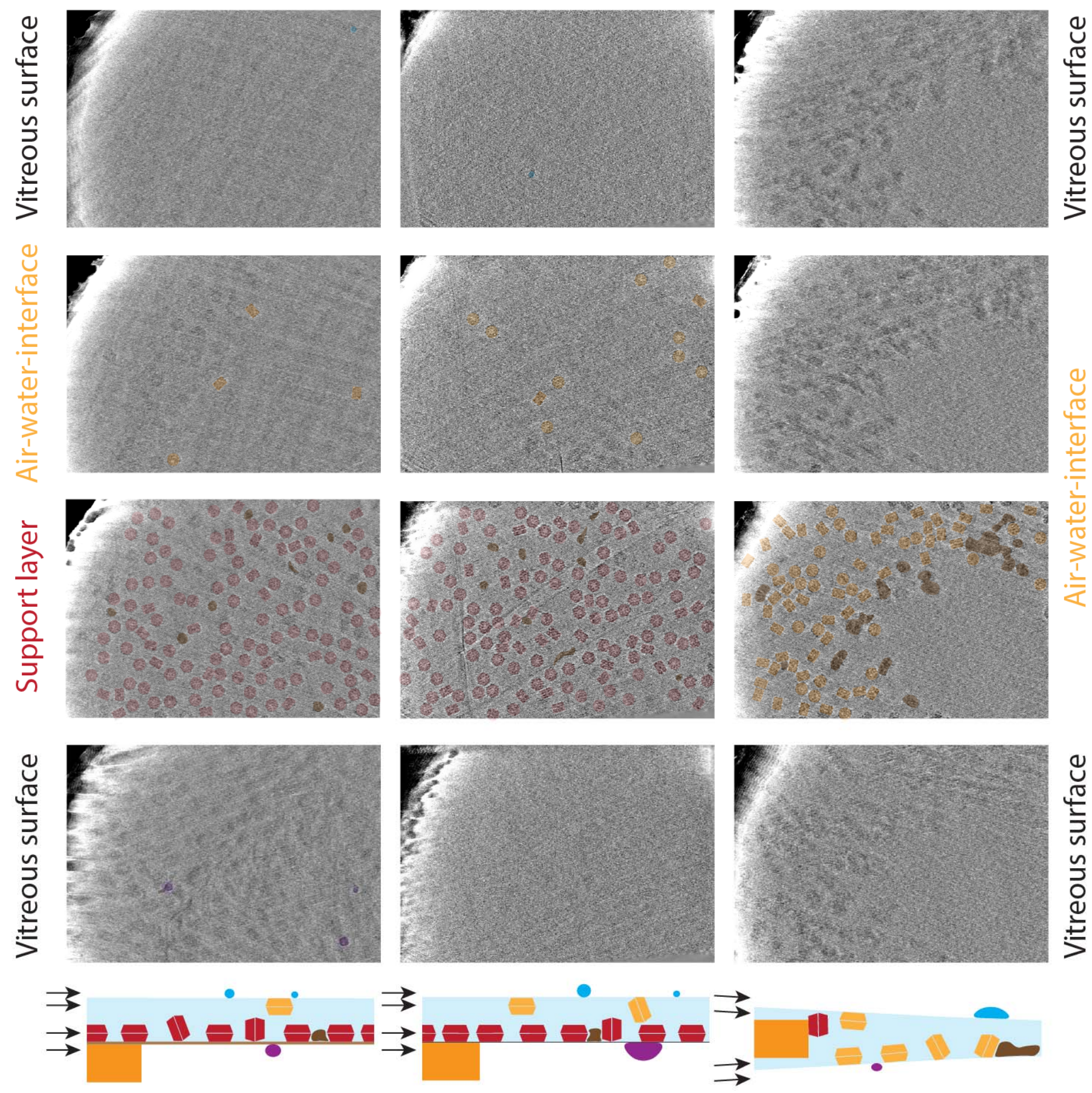

Figure 2 - Figure Supplement 1 | Tomographic slices at different heights in the cryo-EM sample.

Tomographic slices from: (top row) above the vitreous ice layer; (second row) the top of the vitreous ice layer, showing particles bound at the air-water-interface on the blotted side; (third row) the bottom of the vitreous layer, showing particles either bound to the support layer (for AmC or GO grids) or to the air-water-interface (for $\mathrm{OH}$ grids) away from the blotted side; (bottom row) below the vitreous ice layer. Particles are colored based on their distance from the lower surface: red particles bound to the support layer, orange - particles bound to air-water-interface, blue/purple - crystalline ice on the top/bottom of the vitreous ice layer, brown - damaged and aggregated complexes. 
bioRxiv preprint doi: https://doi.org/10.1101/2021.03.08.434344; this version posted March 8, 2021. The copyright holder for this preprint (which was not certified by peer review) is the author/funder, who has granted bioRxiv a license to display the preprint in perpetuity. It is made available under aCC-BY-NC-ND 4.0 International license.

\section{Amorphous Carbon}

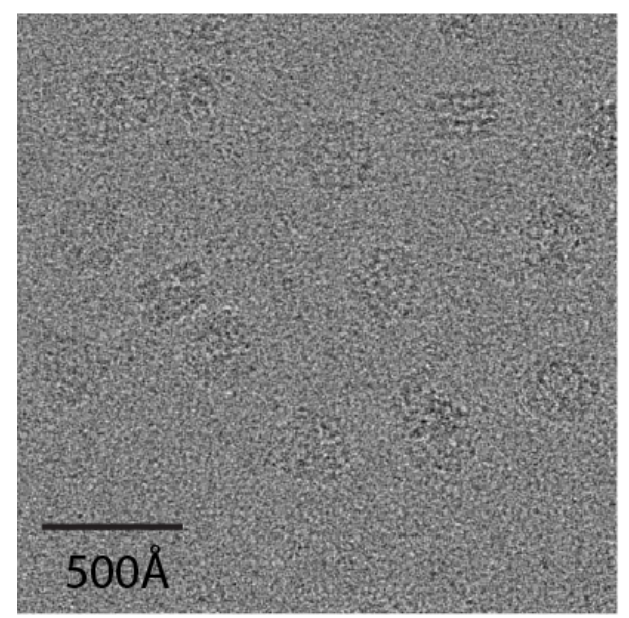

\section{Graphene Oxide}

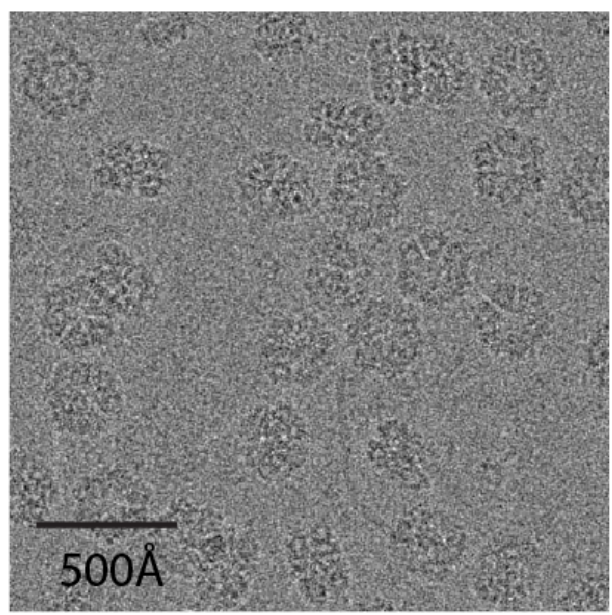

Open Hole

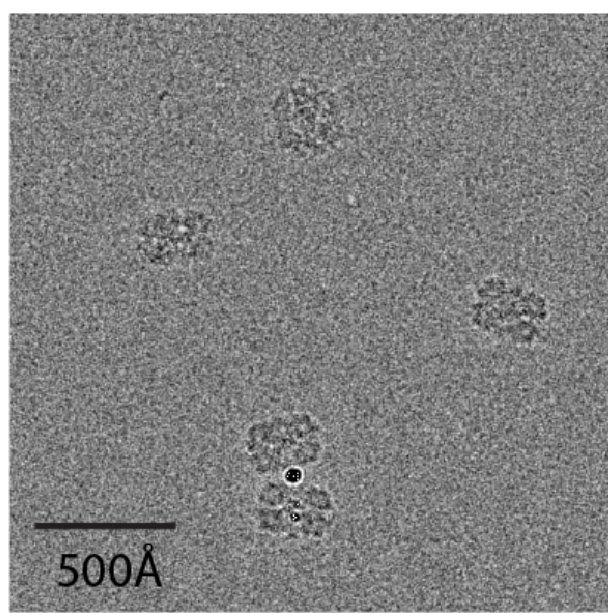

Figure 2 - Figure Supplement 2 | Support layer background.

Representative micrographs from AmC, GO and $\mathrm{OH}$ grids. All images are at $\sim 1 \mu \mathrm{m}$ defocus. 
bioRxiv preprint doi: https://doi.org/10.1101/2021.03.08.434344; this version posted March 8, 2021. The copyright holder for this preprint (which was not certified by peer review) is the author/funder, who has granted bioRxiv a license to display the preprint in perpetuity. It is made available under aCC-BY-NC-ND 4.0 International license.
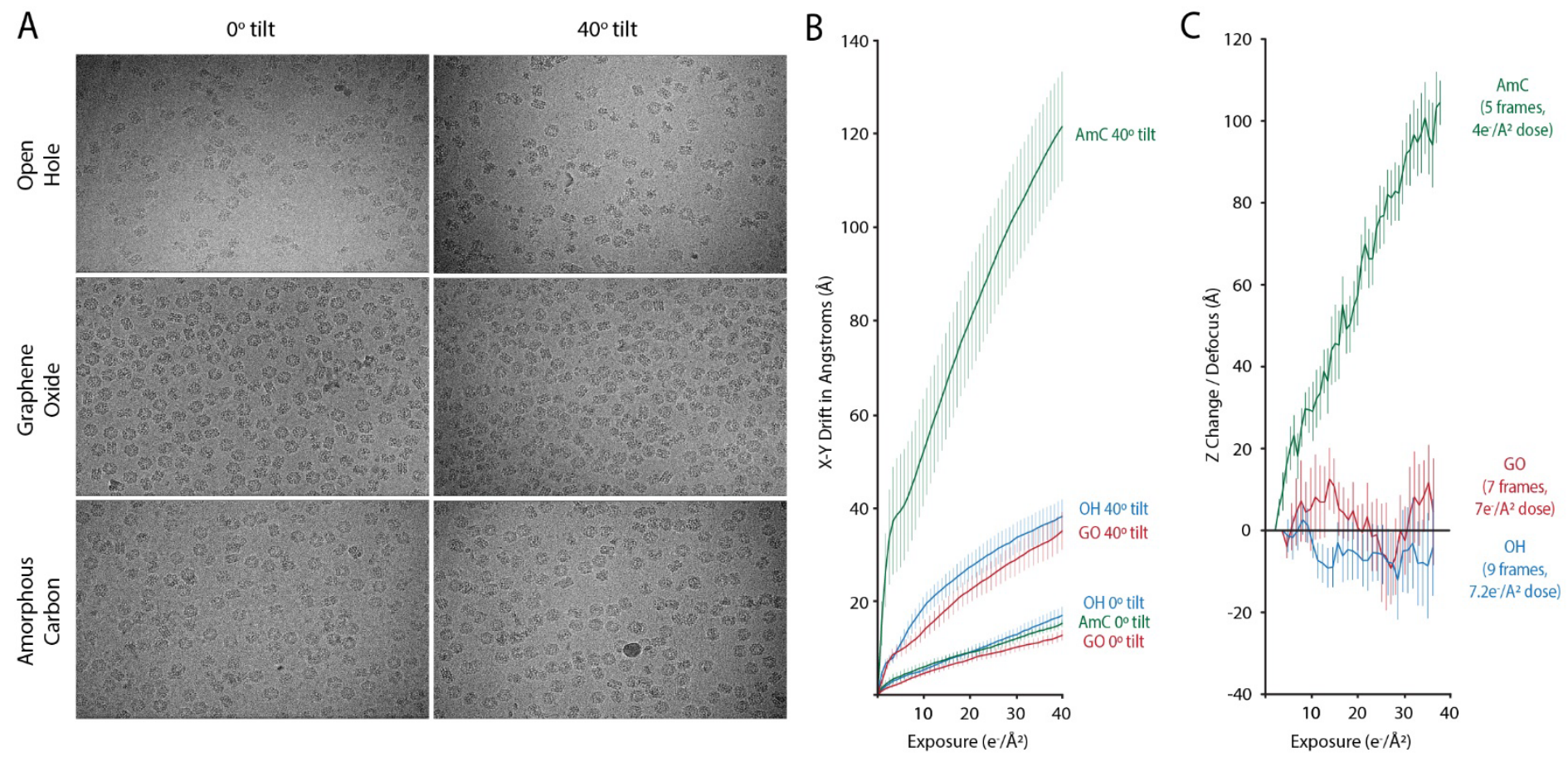

Figure 3 | Sample drift during tilted data collection.

A. Representative micrographs at $0^{\circ}$ and $40^{\circ}$ stage tilt for $\mathrm{OH}, \mathrm{GO}$, and $\mathrm{AmC}$ gold foil grids.

B. Tracks represent the average drift for image collected on $\mathrm{OH}, \mathrm{GO}$, and AmC grids, at both $0^{\circ}$ and $40^{\circ}$. Tracks are averages from ten images, with the vertical lines representing the standard deviation.

C. Measured change in defocus during exposure. For the collected movies, a rolling average of aligned and averaged frames was used to increase the signal of the Thon rings for CTF estimation. Tracks are averages from ten images, with the vertical lines representing the standard deviation. 
bioRxiv preprint doi: https://doi.org/10.1101/2021.03.08.434344; this version posted March 8, 2021. The copyright holder for this preprint (which was not certified by peer review) is the author/funder, who has granted bioRxiv a license to display the preprint in perpetuity. It is made available under aCC-BY-NC-ND 4.0 International license.
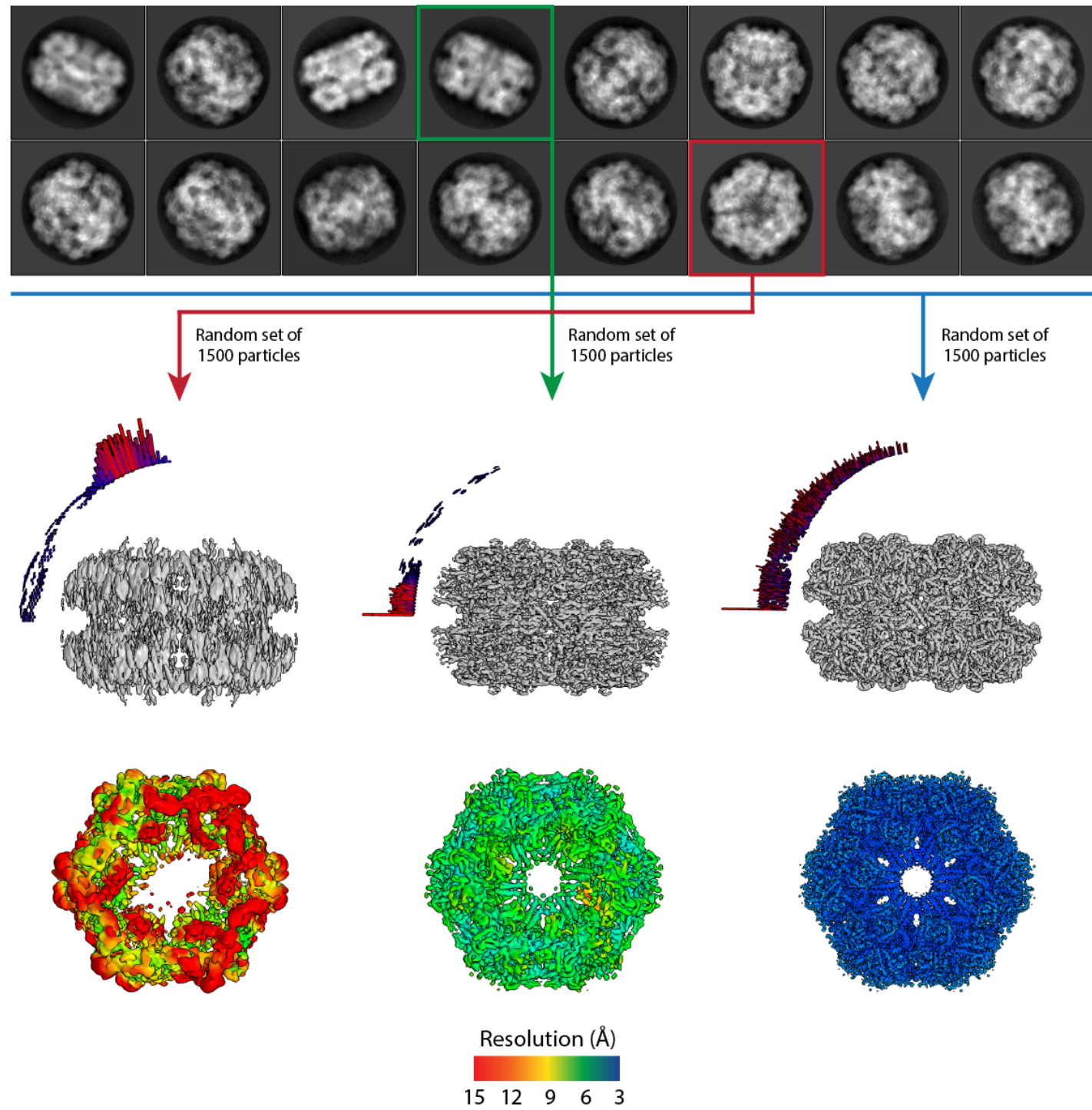

Sphericity $=0.698$ out of 1. Global resolution $=8.64 \mathrm{~A}$

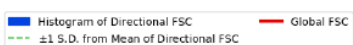

Sphericity $=0.569$ out of 1 . Global resolution $=6.37$

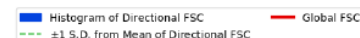

Sphericity $=0.795$ out of 1 . Global resolution $=3.74 \AA$.
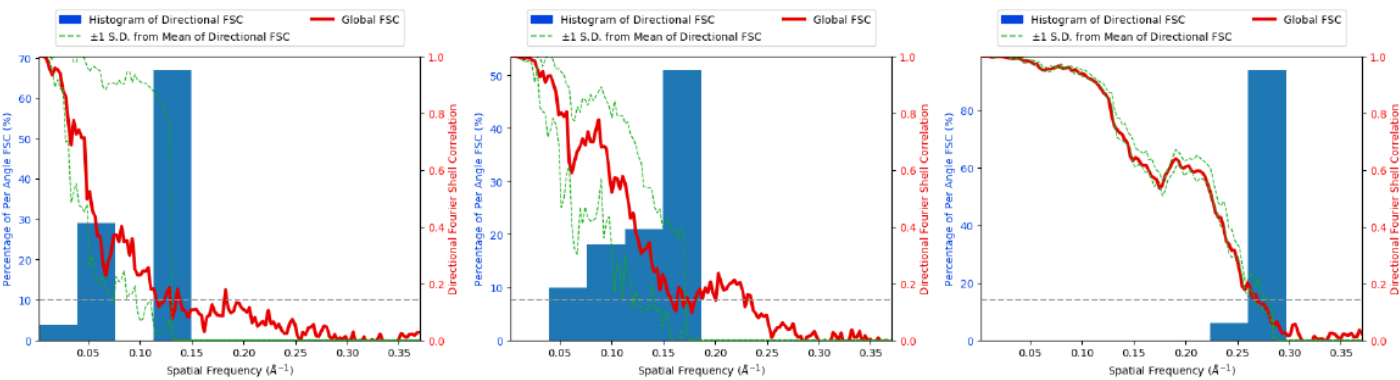

Figure 3 - Figure Supplement 1 | Effect of preferential views on 3D reconstructions.

Erythrocrurin prepared on a graphene oxide coated UltrAuFoil grid collected at a $40^{\circ}$ tilt. From select $2 \mathrm{D}$ class averages 1500 particles were used to generate a 3D reconstruction (with D6 symmetry). The reconstruction on the left was generated from a single 2D class average corresponding to the top view (down the C6 symmetry axis) resulting in an 8.6A reconstruction with a sphericity of .698 as measured by 3DFSC ${ }^{39}$. The map from this reconstruction is very streaky with little interpretable secondary structure. The reconstruction in the middle was generated from a single $2 \mathrm{D}$ class average, perpendicular to the C6 axis, down the C2 symmetry axis, and thus containing six views around the particles C6 axis), resulting in a $6.4 \mathrm{~A}$ reconstruction with a sphericity of .569 . The map from this reconstruction had clearly visibly $\alpha$-helices albeit with some features elongated. The right reconstruction contains a near complete set of views and resulted in map at 3.7A with a sphericity of .795 with clearly visible secondary structure (both $\alpha$-helices and $\beta$-strands), and clear density for large side chains. Reconstructions colored by local resolution as calculated in Relion ${ }^{62}$. 
bioRxiv preprint doi: https://doi.org/10.1101/2021.03.08.434344; this version posted March 8, 2021. The copyright holder for this preprint (which was not certified by peer review) is the author/funder, who has granted bioRxiv a license to display the preprint in perpetuity. It is made available under aCC-BY-NC-ND 4.0 International license.

A

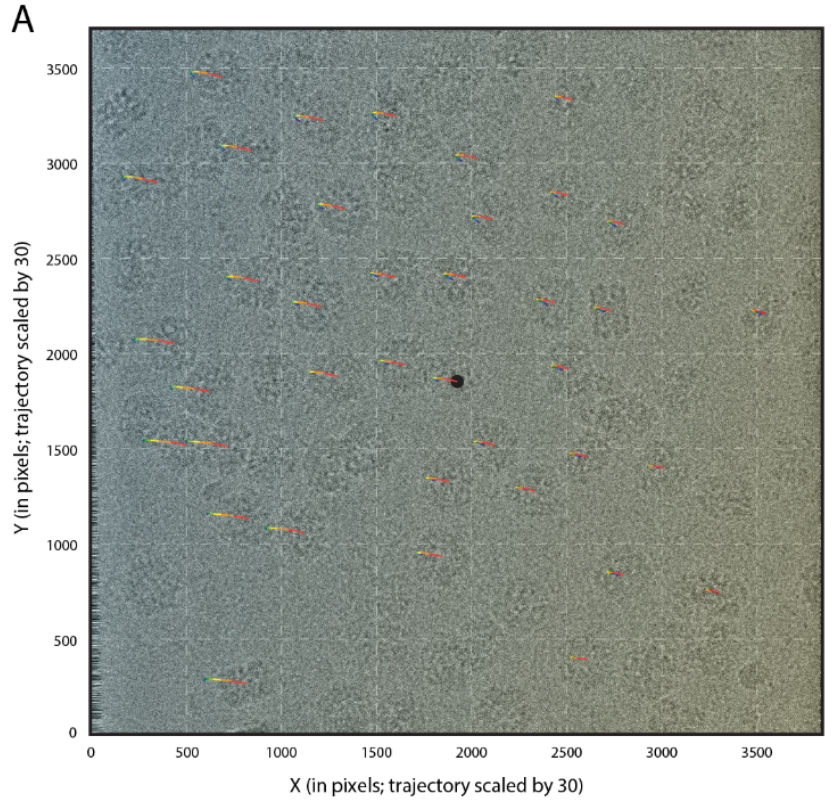

\section{B}

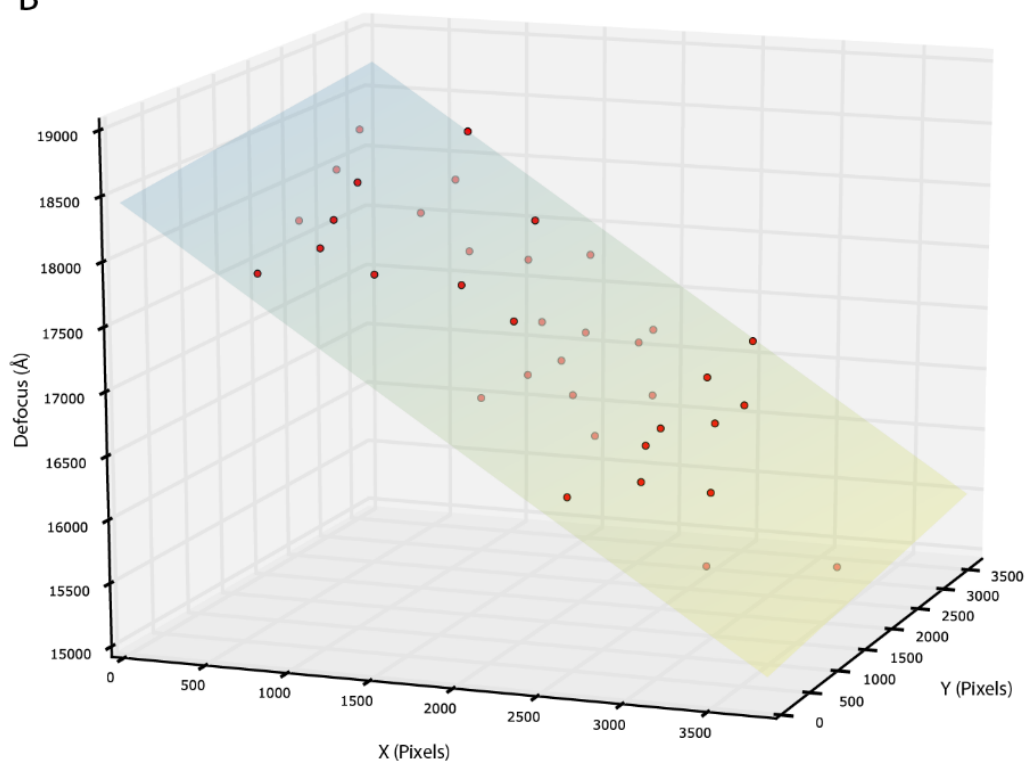

C

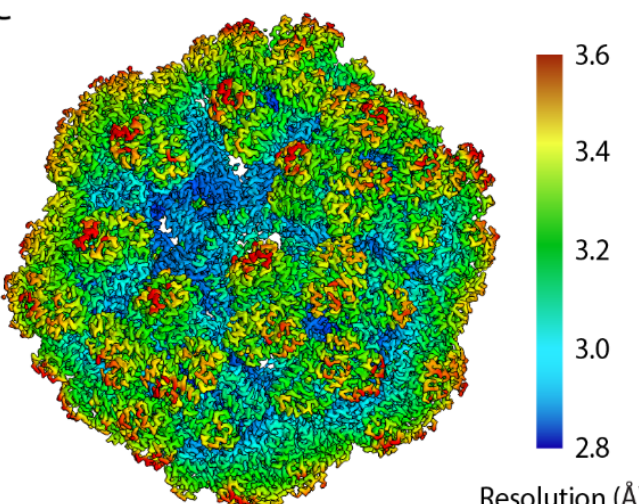

Resolution $(\AA)$
$\mathrm{D}$

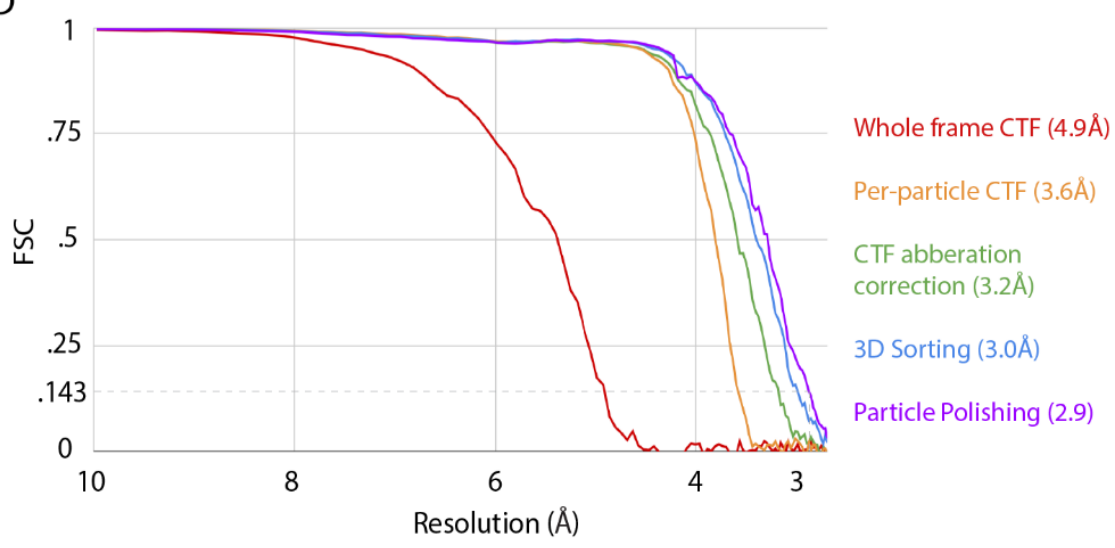

Figure 4 | Collection of titled data on GO coated gold foil grids.

A. Representative erythrocrurin micrograph marking the particles that went into the final reconstruction. Color gradient represent the fitted defocus across the grid (same as in Fig. 4B). Colored lines starting from the center of particles represent a 30 -fold scaled movement of the particle over the course of the movie.

B. Plot of measured defocus across the micrograph with a plane fitted through the points.

C. Reconstruction of erythrocruorin colored by local resolution as computed in Relion ${ }^{62}$.

D. Gold standard FSC curves of reconstruction at various stages of data processing. 
bioRxiv preprint doi: https://doi.org/10.1101/2021.03.08.434344; this version posted March 8, 2021. The copyright holder for this preprint (which was not certified by peer review) is the author/funder, who has granted bioRxiv a license to display the preprint in perpetuity. It is made available under aCC-BY-NC-ND 4.0 International license.

\begin{tabular}{|c|c|c|c|c|c|c|c|c|c|}
\hline \multicolumn{1}{|c|}{ Sample } & MW $(\mathrm{kDa})$ & Res $(\AA)$ & Sym & Mics & Tilted & Particles & Scope $(\mathrm{keV})$ & Camera & Apix \\
\hline Erythrocruorin & 3600 & 2.9 & $\mathrm{D} 6$ & 1588 & $\mathrm{Y}\left(40^{\circ}\right)$ & 30254 & Krios (300) & K2 & .90 \\
\hline 80S ribosome & 3300 & $2.7 / 2.9 / 3.0$ & $\mathrm{C} 1$ & 977 & $\mathrm{~N}$ & 79800 & Arctica (200) & K3 & 1.12 \\
\hline Apoferritin & 470 & 2.6 & $\mathrm{O}$ & 266 & $\mathrm{~N}$ & 7434 & Arctica (200) & K3 & .69 \\
\hline TAF2 & 110 & 2.8 & $\mathrm{C} 1$ & 2402 & $\mathrm{~N}$ & 123033 & Arctica (200) & K3 & .69 \\
\hline
\end{tabular}

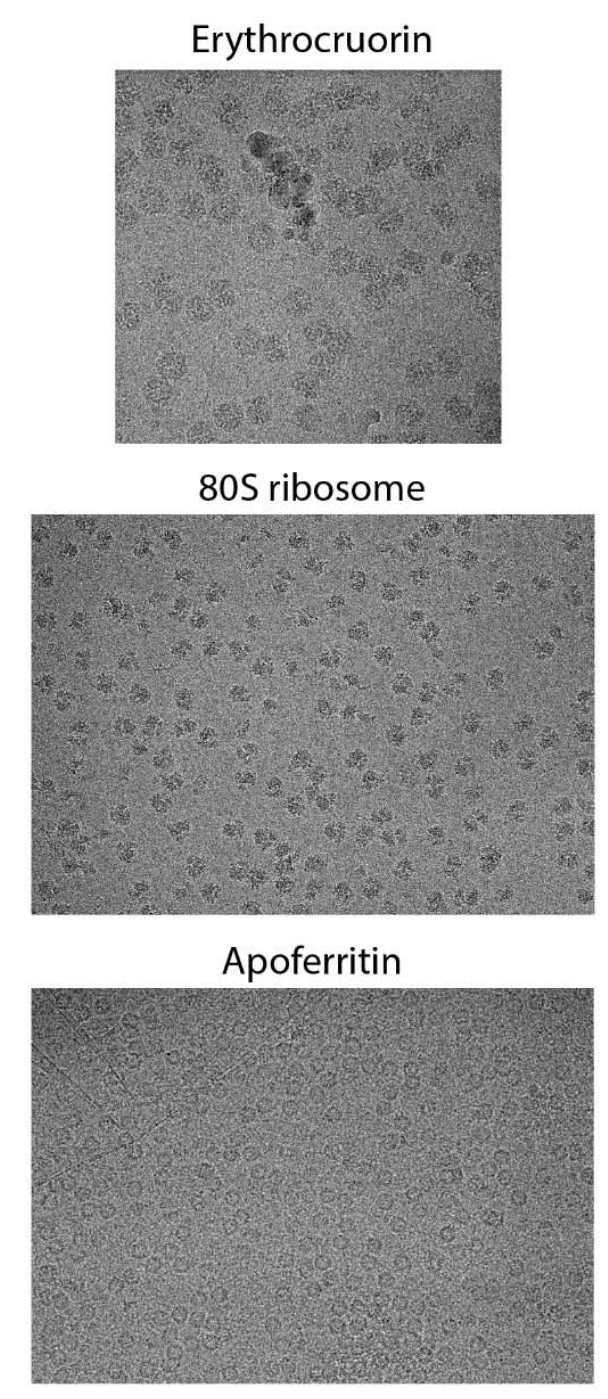

TAF2

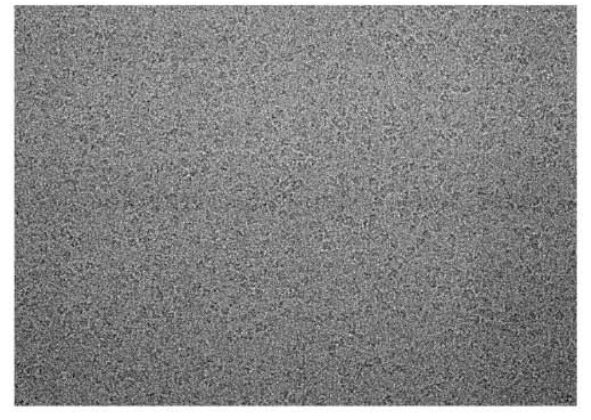

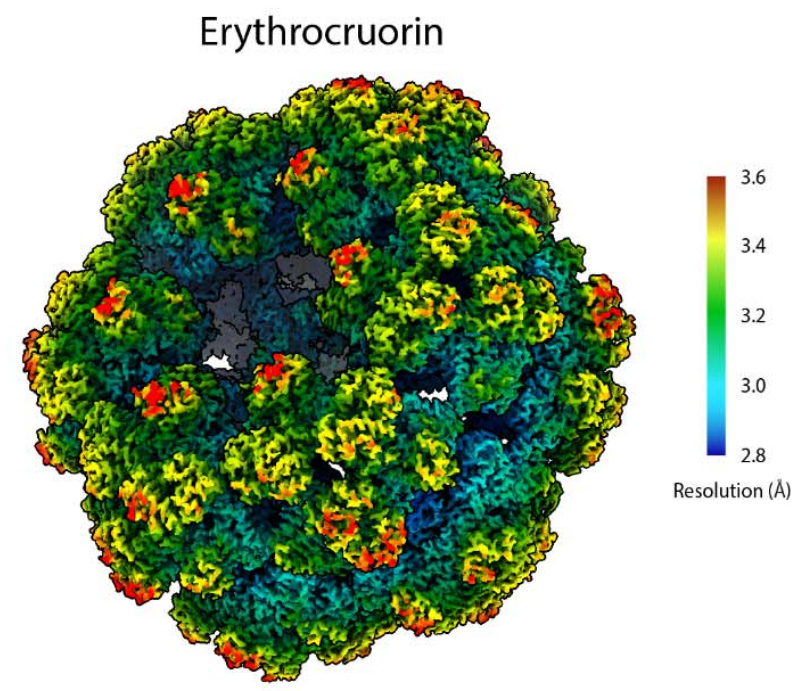
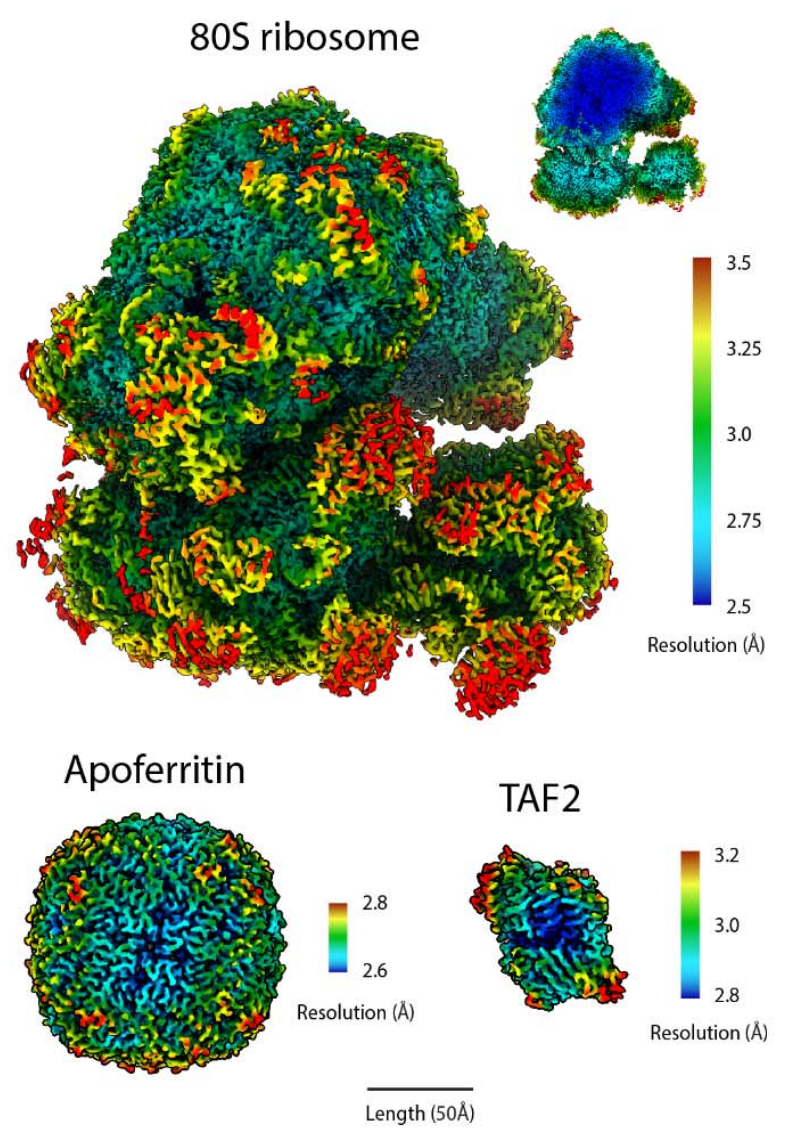

Figure 4 - Figure Supplement 1 | Reconstructions for different samples prepared on GO coated grids.

Top: table summarizing the sample datasets collected on GO coated grids. Bottom left: example micrographs (all at $\sim 1.3 \mu \mathrm{m}$ defocus). Bottom right: reconstructions colored by local resolution as calculated in Relion ${ }^{62}$. Structures shown to scale (except $80 \mathrm{~S}$ ribosome cut through), scale bar at bottom. 